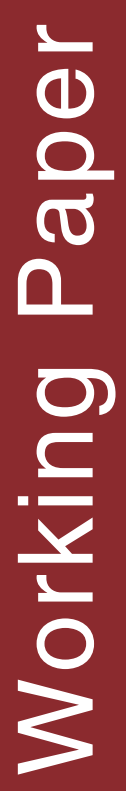

Elok Mulyoutami, Gerhard Sabastian, James M Roshetko 



\section{Gendered Knowledge and Perception in Managing Grassland Areas in East Sumba, Indonesia}

Elok Mulyoutami, Gerhard Sabastian, James M Roshetko 


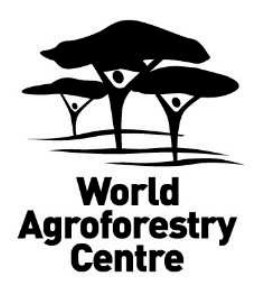

Correct citation:

Mulyoutami E, Sabastian G and Roshetko JM .2016. Gendered Knowledge and Perception in Managing Grassland Areas in East Sumba, Indonesia. Working paper no. 244. Bogor, Indonesia: World Agroforestry Centre (ICRAF) Southeast Asia Regional Program. http://dx.doi.org/10.5716/WP16160.PDF

Titles in the Working Paper series aim to disseminate interim results on agroforestry research and practices, and stimulate feedback from the scientific community. Other publication series from the World Agroforestry Centre include: Technical Manuals, Occasional Papers and the Trees for Change Series.

Published by the World Agroforestry Centre (ICRAF)

Southeast Asia Regional Program

JL. CIFOR, Situ Gede, Sindang Barang, Bogor 16680

PO Box 161, Bogor 16001, Indonesia

Tel: +62 2518625415

Fax: +62 2518625416

Email: icraf-indonesia@cgiar.org

ICRAF Southeast Asia website: http://www.worldagroforestry.org/region/southeast-asia/

(C) World Agroforestry Centre 2016

Working Paper 244

\section{Photographs:}

The views expressed in this publication are those of the author(s) and not necessarily those of the World Agroforestry Centre.Articles appearing in this publication may be quoted or reproduced without charge, provided the source is acknowledged. All images remain the sole property of their source and may not be used for any purpose without written permission of the source. 


\section{About the authors}

Elok Mulyoutami began her research at the ICRAF Southeast Asia Regional Office in 2003, focusing on local ecological knowledge and farming systems. She has a Bachelor of Anthropology degree from Padjadjaran University in Bandung, Indonesia, and Master of Rural Sociology degree at Bogor Agricultural Institute, Indonesia. Her current research focuses on the wider social issues of demography, population, gender and local knowledge issues.

Gerhard Sabastian is an Associate Scientist in Agroforestry System with the World Agroforestry Centre (ICRAF). He has worked for ICRAF with 20 years of experiences in eight projects of research and development in Indonesia. Gerhard is the Project Manager of IRED-ICRAF project. His major research is in smallholder agroforestry systems with focus on the development of silvicultural management for timber and NTFP species to enhance local livelihoods and sustainable ecosystem services. Gerhard has a PhD in Forestry Management from the Australian National University and a MSc in Natural Resources Management from the Bogor Agricultural University.

James M Roshetko is an agroforestry systems scientist with the World Agroforestry Centre (ICRAF). He leads ICRAF Southeast Asia's Trees and Market Unit with 37 years of experience, including 19 years in Indonesia and 28 years in south and Southeast Asia. His research interests are in smallholder tree-based systems as viable agricultural and natural resources management systems that contribute significantly to local livelihood objectives and global environmental goals. He has a $\mathrm{PhD}$ in Geosciences and Natural Resource Management from the University of Copenhagen and a MSc in Forest and Agroforestry Management from Michigan State University. 


\section{Abstract}

Dynamics of land use changes in this earth induce the land quality is often reduced, and the ability to support our livelihood be on the skids. Efforts to recover or restore the land to its original state needs to be done. Gender studies conducted to understand how the roles of women and men in the management of land and other natural resources as part of the restoration process in Haharu Subdistrict, Sumba Timur. Social classes are still prevails in some group of Sumba communities and vertically arranged into three classes, the nobleman, the ordinary people, and the slaverian.

Our finding shows that women and men have almost the same contribution in farming, animal husbandry, and tapping watter as one of productive work in each household. Women seems have more burden in compare to the men, as they have more responsibility in household activities. On the knowledge about land use and land preferences, men's perception usually focus on long term, something related with longterm economic forecast, while women are usually focus on shorter periods and more on economic calculation, reducing the capital through low labour need and low cost on fertilizer. Related to gender relation intra household, we found that there are some weak relation which is showed that not many women has high confidence to evince their opinions. Weak gender relation is getting stronger while we look at the lowest social status. In sum, involvement of men and women in restoration process is essential, but need to take into account the burden and the social strata in the community.

Keywords: Land restoration, land management, gender, social class, Sumba communities 


\section{Acknowledgements}

The authors would like to thank to Bapak Nikolas Hanggawali for his excellent support in facilitating the survey and discussion with local community. High appreciation to Ibu Kitri Widaretna from World Vision International, and most of WVI team based in Sumba Timur who also involve in this activities for their excellent inputs and good coordination. Special thanks to all of the communities in Haharu subdistricts who involve in group discussion and survey. 


\section{Contents}

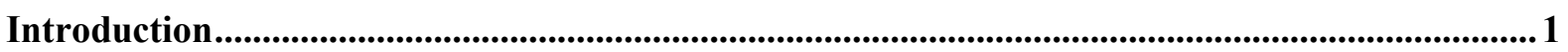

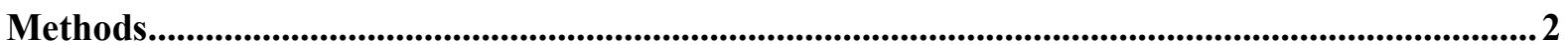

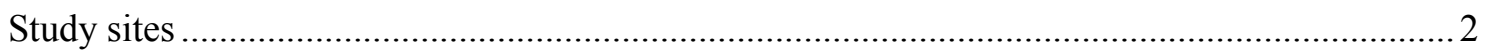

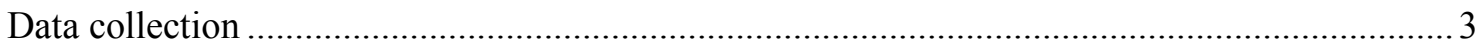

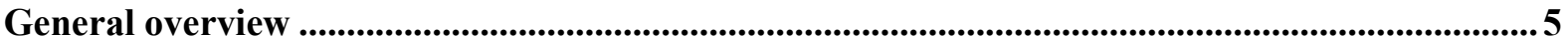

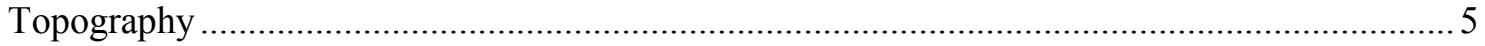

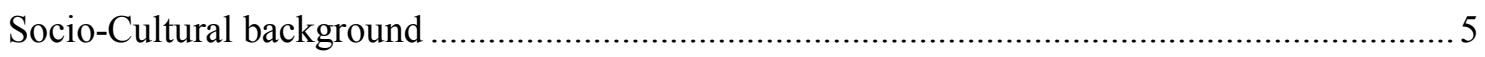

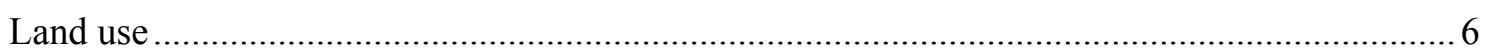

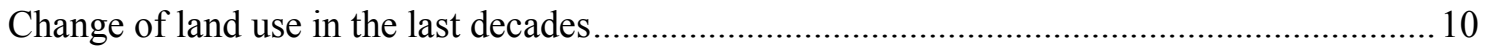

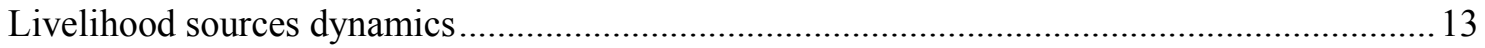

Division of work in household and productive activities......................................................................18

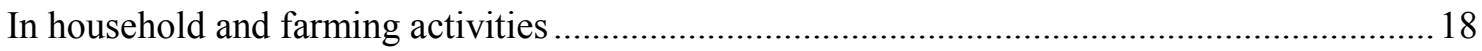

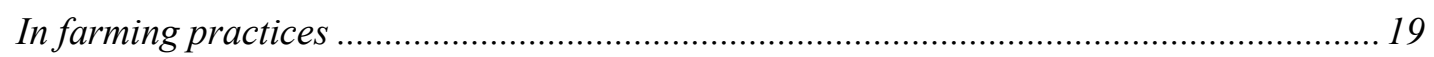

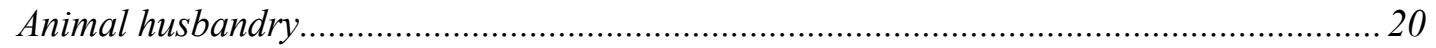

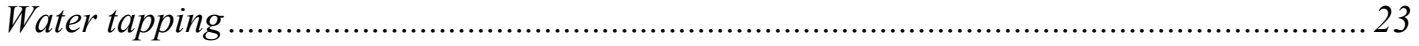

Gendered knowledge and perception .................................................................................................24

Men and Women: how they involve in grassland restoration?..........................................................26

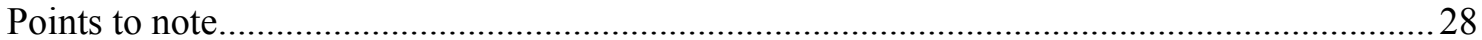

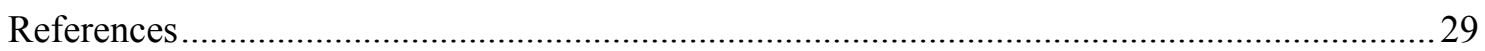




\section{List of Table}

Table 1. Illustration of villages location, topography and natural resources ......................................... 3

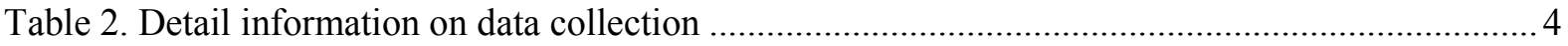

Table 3. Detail description of each land use and landscape in Haharu Sub District, Sumba Timur....... 8

\section{List of Figure}

Figure 1. Landscape view in Haharu Sub District, Sumba Timur ...................................................... 8

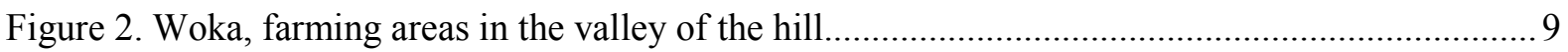

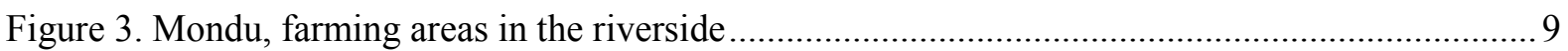

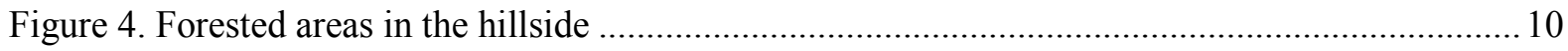

Figure 5. Land use changes from $1990-2025$ based on farmers perception. Data sources: focus

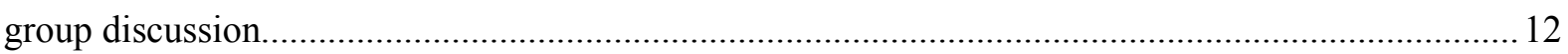

Figure 6. Source of important livelihoods and women involvement in each activities. Data source: group discussions

Figure 7. Change of livelihood sources in two different periods and the projection livelihood sources in the future. Data Source: Focus group discussion................................................................. 18

Figure 8. Gendered role on basic activities in household and farming practices................................ 19

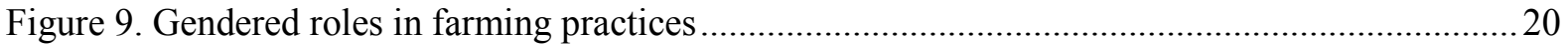

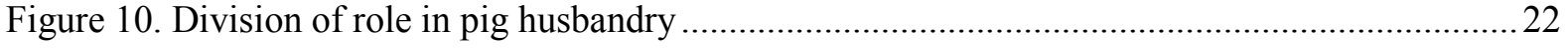

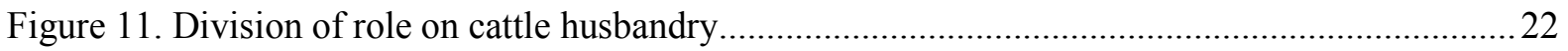

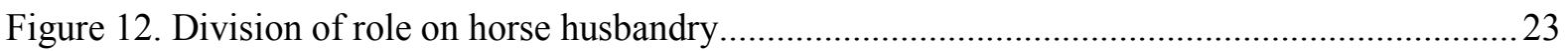

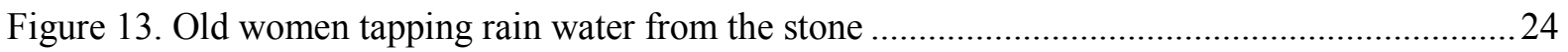

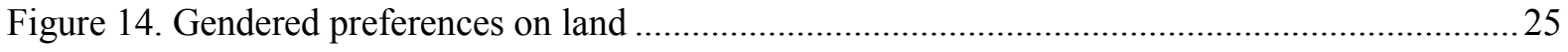

Figure 15. Gendered perception on fire causal factors. Numbers in the bars indicate the median score from all of the discussion numbers in each villages. Data source: focus group discussions. 



\section{Introduction}

Dynamics of land use changes in this earth induce the land quality is often reduced, and the ability to support our livelihood be on the skids. Efforts to recover or restore the land to its original state needs to be done. Communities (farmers) are land managers who best understand their natural conditions, therefore they must be involved in this restoration effort. Discussion about the land managers, we should understand that they are not only a man (or head of households) who becomes land managers, but women (other member in household) are also involved. The selection of plants and land managements often involves women, particularly in certain population groups according to their cultural and social background. Thus, understanding on how women and men involved in managing their land is important as basis in planing more appropriate restoration program.

Pursuing this further, restoration program should be based on local aspiration in order to develop good commitment from local communities as main actor. Therefore, we might know on how to support and facilitate farmers (as the main actor) to regenerate degraded farmlands and forests, increase yields, improve quality, enhance market access and boost their income. As we all are aware, local community has many different layer, on wealth, age structure, social structure as well as gender aspects. We need to make sure that restoration or development program has already represent all the layers exist in the community that direct and indirectly may influences the suceed of the restoration program.

Sumba, is the exotic island in eastern part of Indonesia, with very unique landscape compare to other areas in Indonesia. Expanse of savanna sprawling ground with a number of cattle, goat, horses (ndara) and pigs roam freely enjoying the grass savanna, especially during the rainy season. The stretch of green visible and tidy, in the form of short grass which is accompanied by a group of shrubs scatter (Bakau/Mangrove tree or Sonneratia sp.) and some tall trees (Kehi/KayuCina or Lannea coromandelica) and Kosambi (Scheilecheraoleosa) are grown to cluster. If at first glance the grass just look like planted in a neat, which is in reality just a bunch of grass that can grow in the overlay. The rocks hidden in the ground, and others sticking to the surface with a height of 1 meter to 3 meters and establish the distribution of boulders. Cluster of trees which form like a mini forest were stand in the valleys between the hills of savanna, and, if there are in the plains, the amount of tree is not much and is simply a plant species of kehi tree or locally called as angsana.

This charming landscapes did not promise a decent life for people who live in District Haharu. Its people live in conditions of poverty with the productivity of agricultural land is very low and difficult to get clean water. The landscape that does not have a comprehensive number of stands of trees turned out to only provide minimal water source for the community. Moreover, rocky topography makes people not easy to get the water source

Efforts to restore and/or to make landscape function better was an important step that should be implemented immediately. However, what is most appropriate activity to do? 
Efforts to develop nutrition gardens and maintenance of plants that grow wild in order to develop feasible and can still fulfill forest functions carried out by Wahana Visi Indonesia (WVI), formerly called the World Vision Indonesia, for approximately 10 years. And now, WVI took ICRAF and Lutheran World Relief (LWR) in the project IRED (Indonesia Rural Economic Develeopment) to jointly develop a model of recovery and restoration of the environment of the landscape in the District Haharu without ignoring the importance of improving the livelihood of people living in the area. Inside the IRED project, ICRAF is trying to improve the function of the environment (restoration) of the landscape by building community through the development of priority tree species nursery farmers and improved management of farmland and stands of trees. The resulting seedlings will of course be planted on their farms, and possibly also in other critical locations. The seedlings can of course be sold and provide additional income for the community.

Who actually fits perform the recovery and restoration of the environment of the landscape? Of course, the local community and all the components and social layers in it. They are the main actors in the development of their region, who best understand the physical and social environment and local culture is a factor that must be considered in a packed restoration efforts to be more appropriate. Gender studies conducted to understand how the roles of women and men in the management of land and other natural resources.

This report focus on gender issues in some aspects, such:

1. Assessing on how women and men contribute to household income, and how to empowered women and make their role more visible but not to burdening women in doing their work

2. Understanding different experiences, practices and strategies of both men and women in managing natural resource and addressing environmental problems. Taking into accounts differences between gender is necessary in the course of designing and implementing a development programme.

3. Understanding how differences men and women generate knowledge about environmental changes and making decision over land use. This analysis will be useful to empowered female headed household and also improved the communication between husband and wife in male headed household then men and women may gain the equal benefit.

\section{Methods}

\section{Study sites}

Study was conducted in 7 villages in Haharu Sub-District, Sumba Timur District, East Nusa Tenggra Province, with different topographical condition which lead to different strategies, practices and priorities in their farming practices. Different topographical condition were illustrated in Table 1, and 
the class were defined based on the position of those villages from shoreline, topography position (in the valley, in the plateu, and closeness to forest areas). The land use class were define together with local community through discussion process (FGD).

Table 1. Illustration of villages location, topography and natural resources

\begin{tabular}{|c|c|c|c|c|c|}
\hline $\begin{array}{r}\text { Topograph } \\
y\end{array}$ & & $\begin{array}{l}\text { Villages } \\
\text { grouping }\end{array}$ & $\begin{array}{r}\text { River } \\
\text { availability }\end{array}$ & $\begin{array}{r}\text { Other water } \\
\text { resources }\end{array}$ & Type of major land \\
\hline $\begin{array}{r}\text { Plain and } \\
\text { coastal }\end{array}$ & A & $\begin{array}{r}\text { Kadahang } \\
(20 \text { asl }), \\
\text { Rambangaru } \\
(18 \text { asl })\end{array}$ & $\begin{array}{r}\text { Within the } \\
\text { village }\end{array}$ & \multirow{5}{*}{$\begin{array}{r}\text { Digging well } \\
(26-46 \\
\text { depth) } \\
\text { Rain water } \\
\text { storage } \\
\text { Water tanki } \\
\text { from other } \\
\text { areas } \\
\text { Way Kulup } \\
\text { (water } \\
\text { accumulated } \\
\text { in rock } \\
\text { crevice) } \\
\text { Brackish } \\
\text { lake }\end{array}$} & $\begin{array}{r}\text { Savanna } 25-34 \% \text {, Bareland } 8-18 \% \text {, Woka } \\
\text { (highland garden) } 15-22 \% \text {, Forested areas } \\
(9-14 \%) \text {, Garden in the valley or Lola (only } \\
\text { in Napu } 13 \% \text { ), Homegarden } 11 \% \text {, Mondu } \\
\text { (Riverside garden) } 4-15 \%\end{array}$ \\
\hline $\begin{array}{r}\text { Plain, } \\
\text { coastal, } \\
\text { near to } \\
\text { forested } \\
\text { areas, }\end{array}$ & B & $\begin{array}{r}\text { Napu (207 } \\
\text { asl), } \\
\text { Wunga (234 } \\
\text { asl) }\end{array}$ & No river & & $\begin{array}{r}35 \% \text { Savanna } \\
25 \% \text { Forested areas, } 20 \% \text { of Bareland, } 15 \% \\
\text { of Woka and } 5 \% \text { of Garden }\end{array}$ \\
\hline $\begin{array}{r}\text { Village in } \\
\text { valley areas }\end{array}$ & C & $\begin{array}{r}\text { Kalamba } \\
227 \text { asl } \\
\text { (village in } \\
\text { the couldron) }\end{array}$ & $\begin{array}{r}\text { Within the } \\
\text { village and } \\
\text { Waterfall } \\
\text { Makandoruk }\end{array}$ & & $\begin{array}{r}\text { Savanna } 27 \% \text {, Bareland } 22 \% \text {, Woka } \\
\text { (Garden) } 16 \% \text {, Shrub } 12.5 \% \text {, Homegarden } \\
9 \% \text {, Irrigated paddy } 7 \% \text {, and Mondu } \\
\text { (Riverside garden) } 6.25 \%\end{array}$ \\
\hline \multirow[t]{2}{*}{$\begin{array}{l}\text { Plateu } \\
\text { village }\end{array}$} & $\mathrm{D}$ & $\begin{array}{r}\text { Praibakul } \\
(79 \text { asl) }\end{array}$ & $\begin{array}{r}\text { Within the } \\
\text { village }\end{array}$ & & $\begin{array}{r}\text { Savanna } 22 \%, \text { Homegarden } 19 \%, \\
\text { Woka/Garden, Forested areas and Bareland } \\
11 \%, \text { Mondu } 7.5 \% \text {, Valley garden/Lola } 6 \%, \\
\text { Irrigated paddy } 5 \%\end{array}$ \\
\hline & $E$ & $\begin{array}{r}\text { Mbatapuhu } \\
\text { (375 asl) }\end{array}$ & No river & & $\begin{array}{r}\text { Savanna } 50 \% \text {, Woka Lola } 20 \% \text {, Homegarden } \\
\text { and forested areas @10\%, Bareland and } \\
\text { Woka Palindi @5\% }\end{array}$ \\
\hline
\end{tabular}

\section{Data collection}

Data was collected through series of sex-disaggregration focus group discussion and semi structured interview with some key informant. Focus group discussion were conducted in two phases, the first phases is for general question about the village, this is related to the question of land use change and general livelihood pattern. Phase two is gender disagregrated data group discussion which is conducted in parallel (separate group between men and women) in 6 villages, while in the other one village, due to the village situation contraint, we just conducted semi structured interview using the same set of question as in FGD. Sex-disaggregrated discussion were employed to make sure that women's opinion is not dominated or influenced by the men. However, due to resource limitation, we conducted FGD on the same location with one facilitator, we asked some general question in prior, then its continue by separating men and women, and asking more specific question about their opinion, preferences and strategies. This might be become the resource limitation but then we also can get other advantage to also observe well on how men and women interact each other (during general question were asked). Details data collection methods and participant number as well as informants number were illustrated in Table 2. 
FGDs participants were selected purposively, mostly are the land managers and/or village personage who may have better understanding on village boundary areas, land use, village history and other general information about the village. Ideally, we expect $6-8$ attendees in each groups, however due to certain condition in each villages, we might get more and in few cases we get fewer participants than we expected. Since our analysis is in the group level, the un-balance number of participants is not impair the analysis process. So far, we score the situation in each discussion from 1 to 5 , the highest score indicating the ideal situation on the discussion. We use three categories, the first is about the composition of discussion participant that we expect, for example are they all the land managers who understand the real situation. The second categories is the domination from some of discussion participant, this is to measure whether the discussion have reflecting most of the discussion participant or only several people. The third is the conducive situation of the discussion, we put highest score (5 point) if the condition of has less nuisance. We consider that our discussion participants composition were covering $73 \%$ of our expectation on ideal situation, and the liveliness of participants were about $73 \%$ while the conduciveness is $80 \%$.

In the FGD, we conducted three different participatory approach. The first is, pebble game to assess gender-specific role in natural resource management as describe by Mulyoutami (2014). This game were used to gather information on the main livelihood source and how it changed over time, as well as the information on land use change over period of time. The second is, analytic hierarchy process to assess gendered preferences on land use as describe by Janudianto (2014). The question we used in this game is 'what kind of land use they prefered for restoration program?'. The last approach, is the simple group interview, asking the reason on what are they choices and preferences.

Data analysis using simple descriptive statistic and some simple tabulation using excel programe. Mann-Whitney test were employed to check the differences between men and women.

Table 2. Detail information on data collection

\begin{tabular}{|c|c|c|c|c|c|c|}
\hline \multirow[t]{2}{*}{ Villages } & \multicolumn{2}{|c|}{$\begin{array}{r}\text { Number of FGD (and the } \\
\text { participants) }\end{array}$} & \multicolumn{2}{|c|}{ Individual interview } & \multicolumn{2}{|c|}{$\begin{array}{r}\text { Total respondent } \\
\text { and informants }\end{array}$} \\
\hline & Men & Women & Men & Women & Men & Women \\
\hline Kadahang & $1(13)$ & $1(5)$ & 1 & - & 14 & 5 \\
\hline Kalamba & $1(13)$ & $1(5)$ & 1 & 1 & 14 & 6 \\
\hline Mbatapuhu & $1(8)$ & $1(7)$ & 1 & - & 9 & 7 \\
\hline Napu & $1(6)$ & $1(5)$ & 1 & 2 & 7 & 7 \\
\hline Praibakul & $1(9)$ & $1(11)$ & 1 & 1 & 10 & 12 \\
\hline Wunga & $1(10)$ & $1(7)$ & - & - & 10 & 7 \\
\hline Rambangaru & - & - & 3 & 2 & 3 & 2 \\
\hline Total & $6(59)$ & $6(40)$ & 8 & 6 & & \\
\hline
\end{tabular}




\section{General overview}

\section{Topography}

The topography of Sumba Timur is generally flat (in the coastal areas), gently sloping to undulating (lowland region $<100$ meters) and hilly (mountainous). Areas with altitudes above 1000 meters slightly in the hills and mountains. The range of mountains and steep limestone hills that dominate the area center in areas near Kalamba village. Agricultural land mainly in the northern coastal plains that have enough surface water and big rivers.

This district tropical climate with rainy season is relatively short and the long dry season (eight months). The average temperature was 22.5 degrees to 31.7 degrees Celsius, so this area includes dry climates. Total rainfall of 1,860 millimeters a year, with rainy season usually occurs in December and Marc. In most of Sumba Timur District, water deficit happened due to low water availability, both from lack of ground water recharge as well as low rainfall.

Meadows spread out across vast plains, as well as hilly terrain, thus forming a small mound with extensive lawns adorned several groups of trees. Rocky meadows are also found in some areas. It sometimes become the benefit, while water were trapped in the rock crevice and use as livestock drinking water source.

\section{Socio-Cultural background}

Sumba Timur embraced patrilineal system, with wife entered into husband's clan and their descendants involving their rights and obligations. Patrilineal kin group called kabihu. A wife goes into a clan of her husband, as well as their children directly into the clan of his father with all the rights and obligations. The form of traditional marriage of Sumba is exogamy (asymmetric comnubium) marriage performed outside kabihu with unidirectional relationship (Soelarto 2000). Exchange of goods in marriage, where the groom (men's) should pay belis or bridewealth (wili, weli) and the countergift (Mbola ngandi), "Basket of the bride". Bridewealth can be livestock, mainly horses, buffalo, and pig, and countergift usually cloth ( $k a m b a)$.

J J Fox (1980) mention that female goods move in the same direction as the woman who marry out, while male goods go in the opposite direction, as gifts to the bride's family. Female goods given by the brides family include pigs, cloths and ornaments. One special task of young woman at her new home is tauna peni manu or tauna nga'a wasi (feed chicken or pig).

Kinship according kabihu (tribe/clan) is very strong, as reflected in various community activities. Kabihu (clan) play a pivotal role as a unit community cohesion. Each Kabihu has rights, priviledge, and obligations that would depent on their tradition and history that was developed by their ancestors. Paraingu is a territory ruled by community rules that was developed by several kabihu/clan who established the Paraingu. In simple, paraingu allied with village. 
Social classes are vertically arranged into three classes, Maramba, Kabihu and Ata (Fox 1980, Forshee 2001, Melalatoa 1995). Maramba is the nobleman, the highest caste who usually controlling and overcome the resources. Kabihu are the ordinary people (middle class), they all independent, and majority of the community member were from Kabihu caste. The lowest caste is Ata, or slaverian, the one who should serve the nobleman. They don't have right to make decision on their own life, they should follow what the nobleman commanded. Actually, the relationship between the nobleman, the ordinary people and the slaves corresponding the relationship of father and son (Wellem 2004), the nobleman should protect the community. Nobleman called as ina ma paraingu, ama la paraingu (father and mother of the community). The same as nobleman that can only get by inheritance systems, the ata caste were also can be inherited from one generation to other generation. Once people become the Ata, they and their descendent family will become Ata forever.

Currently, social classes is no longer strongly applied due to the number of nobleman and ata is on the wane. However, in some villages, where maramba still exist, the relationship nobleman - slave still also exist, but might be changed. This aristocratic system is almost fading due to the function of the nobles had slowly changed (Renda 2012). The nobles who usually has prerogative right to controlling all of human aspects in the community, but now only in a few sectors. Secondly, influence of new religion, technology developments that affect to the change of mindset of local people. The loyalty to the nobleman is decreasing. The traditional three tiered social hierarchy is almost replaced by the egalitarian classless society.

\section{Land use}

The expanse of Haharu district covering with grass hill, patchy of forest in valleys areas, and stone spread over on the grass land, starting from the coastal plain ( 0 asl) areas up to 375 meters above see level. Due to the small amount of standing trees, the areas appears to be open and we can see all the land curves. Grass hill were become the domination landscape in particular in highland and inland areas. The crowd of standing trees were usually appears in valley areas like a small forest, near the stream. Sandstone cliff also appears in some areas in particular on the way to Kalamba village, the village of the couldron.

Most of the land in Haharu district were owned communaly as tanah adat or belong to the clan or Kabihu.There were also land that owned individually and the owner paid for the tax. Land titled only they get based on the letter of 'land and building tax'. Only housing areas, productive garden near the house, or some productive garden near the settlement areas that have the land titled. Figure 1 shows the main topographical position of land in Haharu district and all of the farming practices in each areas. There were five main land use practices in Haharu.

Mondu (A), is the land in the riverside or near other water sources. Since river usually located in valley areas, mondu is almost practices in valley areas. Maize (Zea Mays), sweet potato (Dioscorea alata) and some kind of vegetables as tomatto (Solanum lycopersicum), chilly (Capsicum annuum L.), 
long bean (Vigna unguiculata sesquipedalis), as well as fruit trees were deliberately cultivated by clan of farmers in this areas. Fruit trees were maintained not only for the products, but also to protect the land from flood. While wooden trees, were still maintained there, aside to land protection, but also as the life fence avoiding the livestock entering their farming areas. While mondu is usually the garden on the riverside with maximum distance from the river edge is about $2-3$ meters, Tana Ping were also riverside garden but more to inland areas, with distance from the river edge is more than 3 meters. Mondu and Tana Ping ownership were usually based on traditional claim and belong to certain clans. People who are not in the clan were still possible to managed the land, they may borrowed the land.

Woka is the term refering the productive land in dry areas. Most of vegetation planted there, such as maize, peanut (Arachis hypogaea L), any kind of vegetables, coconut (Cocos nucifera), etc, are growth depend on rainfall. Woka Lola (B), is the areas in valley area without any river nearby. The valley areas were used because it has good fertility and less stone, so they could manage the land more efficient. Woka Palindi (C) (Woka Palendu), the productive dry land located in the plateu. Woka, that close to the settlement areas were called as Woka Uma, and it refered to homegarden, the productive land surrounding the house. Most of the vegetation they plant in Woka Lola can also be planted here.

Maradda (padang - sumba term or sabana - Indonesia term) or Savanna spread widely both in the highlands, as well as in the lowlands. Savanna's become an area that is used for the location of grazing livestock, some of them were also covered with huge stone. Savanna ownership usually through clan lines, and often closely related to a social status. However, people are still allowed to use any savanna areas for grazing, some people mention that the location for grazing usually based on the closeness to the settlement areas, other argue that it can relate to the clan. Maramba generally have a broad savanna areas. In some villages, Mbatapuhu and Praibakul for example, in 1990s is the era of granting residential land to the landless majority community. Some of savanna's areas were divided to settlement areas, and may get land titled from National Land Agency, though this raised some social conflicts and jealousy.

Utang or forested areas (D) areas were mainly naturally covered the valleys areas. This might due to the soil condition there were more fertile, and the stone in the soil is less. Natural vegetation may growth in this areas are Kesambi (Scleicera oleosa), Bidara/Kom (Zizipus Jujube), lamtoro (Leucaena leicocephla), Beringin (Ficus sp), Mojo/Maja/Wabiila (Aegle marmelos Correa), Mengkudu (Morinda citrifolia) dan Kedondong hutan (Spondias pinnata), Kasuarin (Casuarina Junghuhiana), Kayu Merah (Pterecarpus Indicus), Johar (Cassia Siamea), Aisuli (Acacia Oraria) and akasia (Acacia auriculiformis). There were 3375 ha forested areas in Haharu Sub-district assigned as 'Production Forest' as part of the total 58422 of 'Forest Production' areas in Sumba Timur district. 


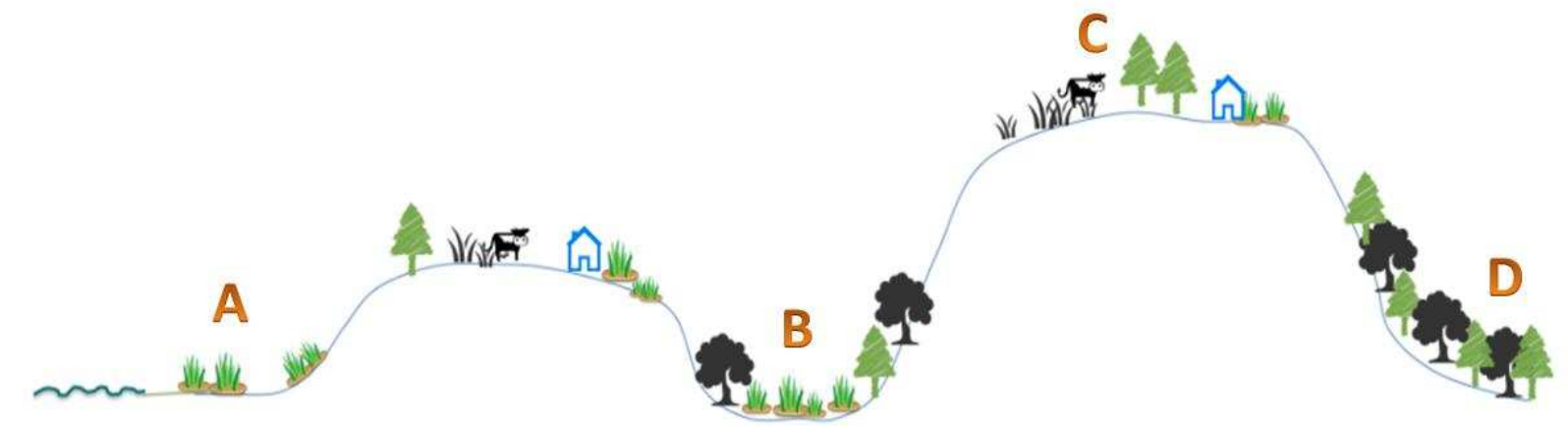

Figure 1. Landscape view in Haharu Sub District, Sumba Timur

Table 3. Detail description of each land use and landscape in Haharu Sub District, Sumba Timur

\begin{tabular}{|c|c|c|c|c|c|}
\hline Land use & A Mondu & $\begin{array}{l}\text { Maradda } \\
\text { (Savanna) }\end{array}$ & B Woka lola & $\begin{array}{l}\text { C Woka: } \\
\text { Woka palindi, } \\
\text { woka uma }\end{array}$ & $\begin{array}{l}\text { D Forested } \\
\text { areas }\end{array}$ \\
\hline \multirow{6}{*}{$\begin{array}{l}\text { Type of } \\
\text { vegetation }\end{array}$} & Wet Paddy & Kehi trees & Dried Paddy & Maize (Kamboru) & Kehi \\
\hline & Maize, Sweet & \multirow{5}{*}{$\begin{array}{l}\text { Grass } \\
\text { (Pennisetum } \\
\text { spp). }\end{array}$} & \multirow{5}{*}{$\begin{array}{l}\text { Maize, Sweet } \\
\text { potato } \\
\text { Sorghum } \\
\text { (Watar Hamu) }\end{array}$} & Cashew & \multirow[t]{5}{*}{ Teak } \\
\hline & potato & & & Kehi trees & \\
\hline & \multirow{2}{*}{$\begin{array}{l}\text { Tomato } \\
\text { (Ambalai), Chilly } \\
\text { (Bokuhawu), } \\
\text { Paria, Labu } \\
\text { (Kallah). }\end{array}$} & & & $\begin{array}{l}\text { Kacang tanah } \\
\text { (Manila) }\end{array}$ & \\
\hline & & & & $\begin{array}{l}\text { Kacang turis } \\
\text { (Kacang gude) }\end{array}$ & \\
\hline & Fruit trees & & & Coconut (Kokur) & \\
\hline \multirow{3}{*}{$\begin{array}{l}\text { Soil type } \\
\text { (local } \\
\text { perception) }\end{array}$} & Black soil & \multirow{3}{*}{$\begin{array}{l}\text { Sandy soil } \\
\text { Grey soil }\end{array}$} & \multirow{3}{*}{$\begin{array}{l}\text { Black Soil } \\
\text { Grey soil }\end{array}$} & Red soil & \multirow{3}{*}{$\begin{array}{l}\text { Black soil } \\
\text { Fertile }\end{array}$} \\
\hline & Sandy soil & & & Black soil & \\
\hline & Mixture soil & & & White soil & \\
\hline $\begin{array}{l}\text { Gender } \\
\text { roles }\end{array}$ & & & Men and Women & & \\
\hline \multirow[t]{2}{*}{$\begin{array}{l}\text { Water } \\
\text { sources }\end{array}$} & \multirow[t]{2}{*}{ Nearby river } & \multirow[t]{2}{*}{$\begin{array}{l}\text { Water } \\
\text { storage in } \\
\text { crevice stone }\end{array}$} & \multirow{2}{*}{$\begin{array}{l}\text { Small spring } \\
\text { Rain water } \\
\text { storage }\end{array}$} & $\begin{array}{l}\text { Rain water } \\
\text { storage }\end{array}$ & \multirow{2}{*}{$\begin{array}{l}\text { Small } \\
\text { spring } \\
\text { Rain water } \\
\text { storage }\end{array}$} \\
\hline & & & & Wells (few) & \\
\hline $\begin{array}{l}\text { Time for } \\
\text { cultivating }\end{array}$ & $\begin{array}{l}\text { End of rainy } \\
\text { season } \\
\text { (avoiding flood) }\end{array}$ & - & $\begin{array}{l}\text { During rainy } \\
\text { season (depend } \\
\text { on rain water) }\end{array}$ & $\begin{array}{l}\text { Plant during rainy } \\
\text { season, but can } \\
\text { be cultivated } \\
\text { through the years }\end{array}$ & - \\
\hline $\begin{array}{l}\text { Tenurial } \\
\text { issues }\end{array}$ & $\begin{array}{l}\text { Communal land, } \\
\text { individu who can } \\
\text { manage the land } \\
\text { usually from the } \\
\text { same clan, or if } \\
\text { its not, they } \\
\text { should get } \\
\text { special } \\
\text { permission from } \\
\text { the clan of the } \\
\text { land owner }\end{array}$ & $\begin{array}{l}\text { Communal } \\
\text { (clan) land } \\
\text { It can be } \\
\text { utilize by } \\
\text { everybody in } \\
\text { Paraingu } \\
\text { (villages) }\end{array}$ & $\begin{array}{l}\text { Some of land } \\
\text { were belongs to } \\
\text { communal land, } \\
\text { though in some } \\
\text { areas woka lola } \\
\text { were also } \\
\text { owned } \\
\text { individually }\end{array}$ & $\begin{array}{l}\text { Usually owned } \\
\text { individually }\end{array}$ & $\begin{array}{l}\text { Communal } \\
\text { land } \\
\text { (sometimes } \\
\text { its } \\
\text { belonging } \\
\text { to the } \\
\text { maramba) }\end{array}$ \\
\hline
\end{tabular}


Non (semi) productive land use were also indicated, they called as Ramang and Kanguma. Ramang indicated the bare land, usually its owned but without land tittle. Kanguma, is also the bareland, located in steep valley areas, and usually planted with lamtoro (Leucaena leicecophla). Some people may utilized the kanguma areas to plant vegetables.

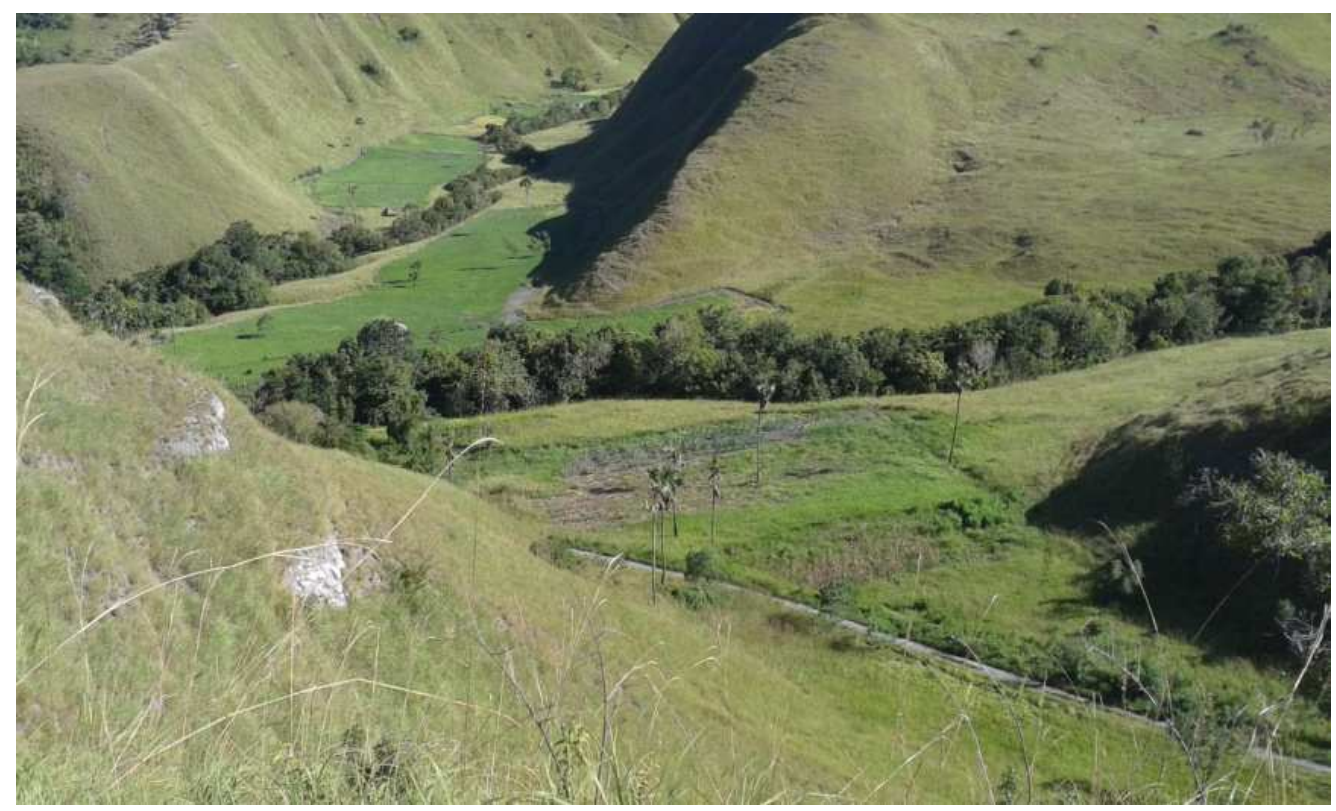

Figure 2. Woka, farming areas in the valley of the hill

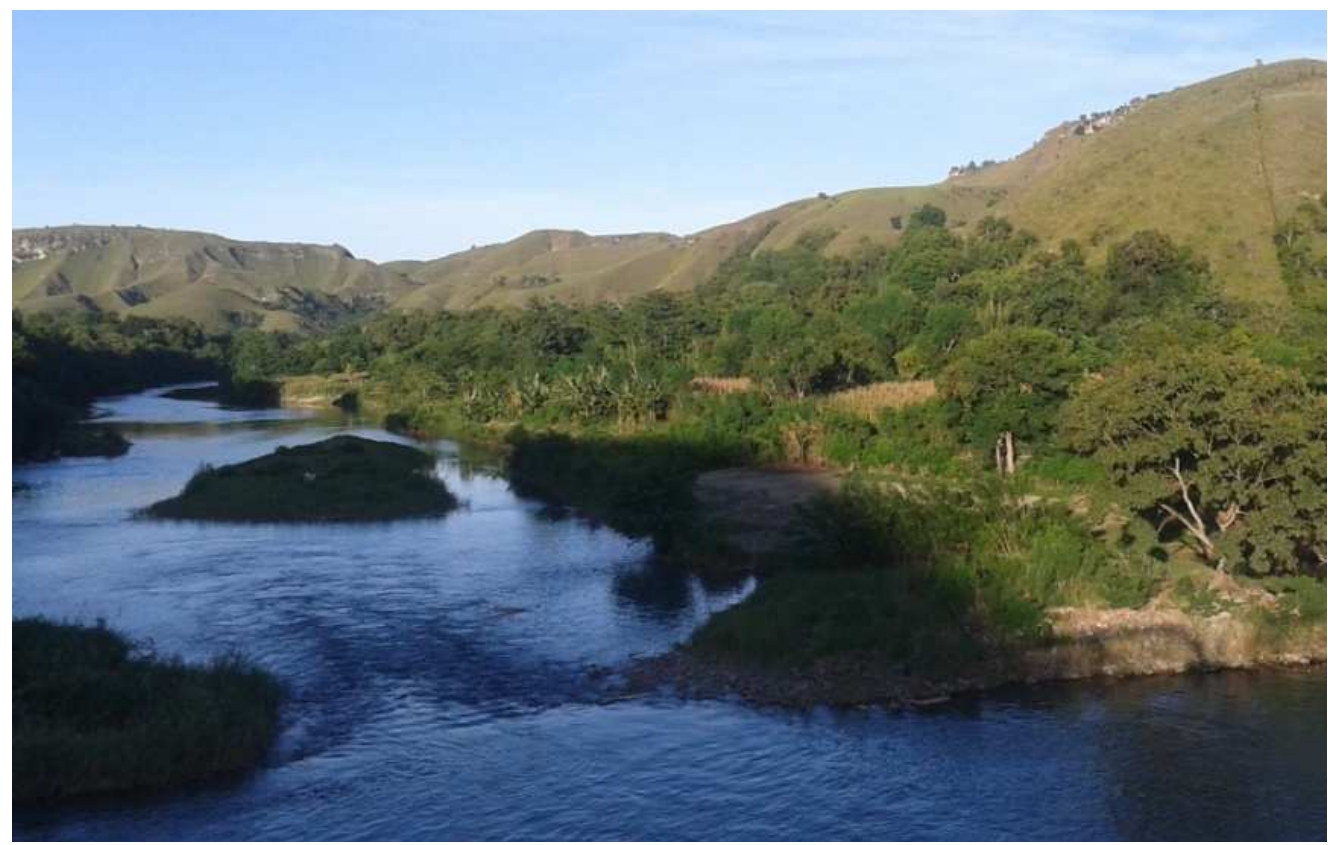

Figure 3. Mondu, farming areas in the riverside 


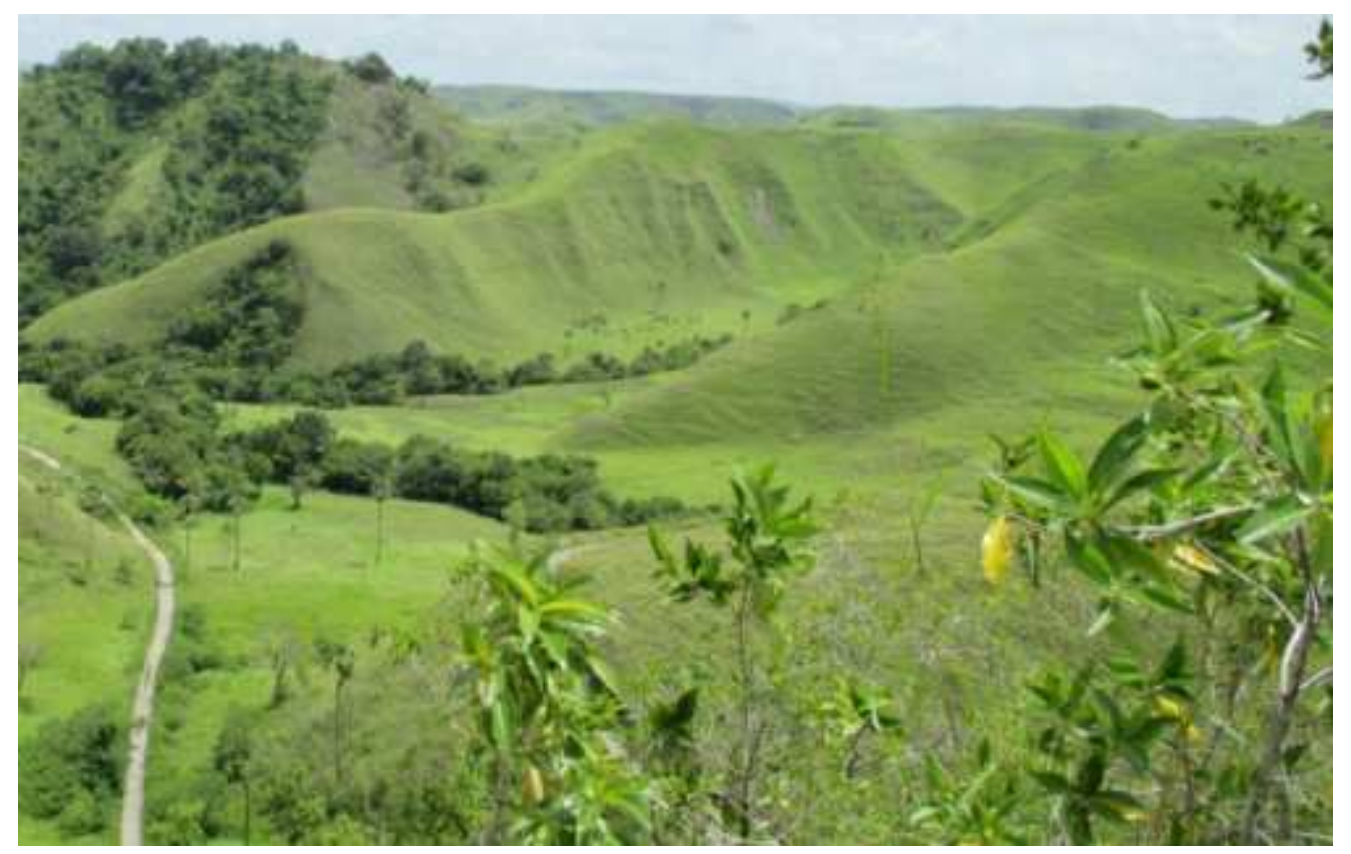

Figure 4. Forested areas (utang) in the hillside

\section{Change of land use in the last decades}

This part illustrating how the major land use in the surveyed village change from time to time (presented in figure below). Land use change illustration were taken from the farmers' point of view. In focus group discussion series that was conducted in some villages, we asked farmers to indicate how the land use size for periods of 1990, 2000, 2015 and what will be the estimation of land use available in their village on 2025 based on current condition. Since the information is based on farmers perception, the information on those figures will not very accurate, but it can show the tendency of what are the largest and smallest land use in each villages.

Figure 5 shows that from 1990 to 2015, savanna were always be the vast land in each villages areas, although currently has begun to wane and change to other productive land use systems (woka or mixed garden in dry areas) and settlement areas (including homegarden or locally called as Ana Woka). Woka area expansion increase, indicating that people started to be more intensive cultivating their fields. People utilize bare land (ramang) and shrubs areas (kangoma) for intensifying their farming practices. For people living in the highland, mondu and lola are the important land use to produce vegetables and other source of food, as well as fruits. Due to the topography, access to mondu and lola usually slightly difficult because the location is in lowland. Some people living in the highland are still maintained woka in the highland area that is near their home.

Homegarden areas expand due to the expansion of settlement areas. In mid of 1990s, local governments have resettled program with opening new settlement territories in highlands. The area that they use are mostly the savanna. The program is conducted to move the people who originally 
settled in the valley-floodplain areas to the highland areas. Each household may get $0.075-0.1$ ha of land for housing and home garden.

The coverage of forested areas still remained the same in the decades. Those tendency is happened due to the low interest of people to cut the trees. Labor issues become the main reason as it mention by the focus group discussant. People just managed the shrubs areas in the forested areas, sometimes collect deadtree as firewood. They may also collect fuelwood from the bareland areas to fulfil the needs for household consumption.

\section{(A) Kadahang}

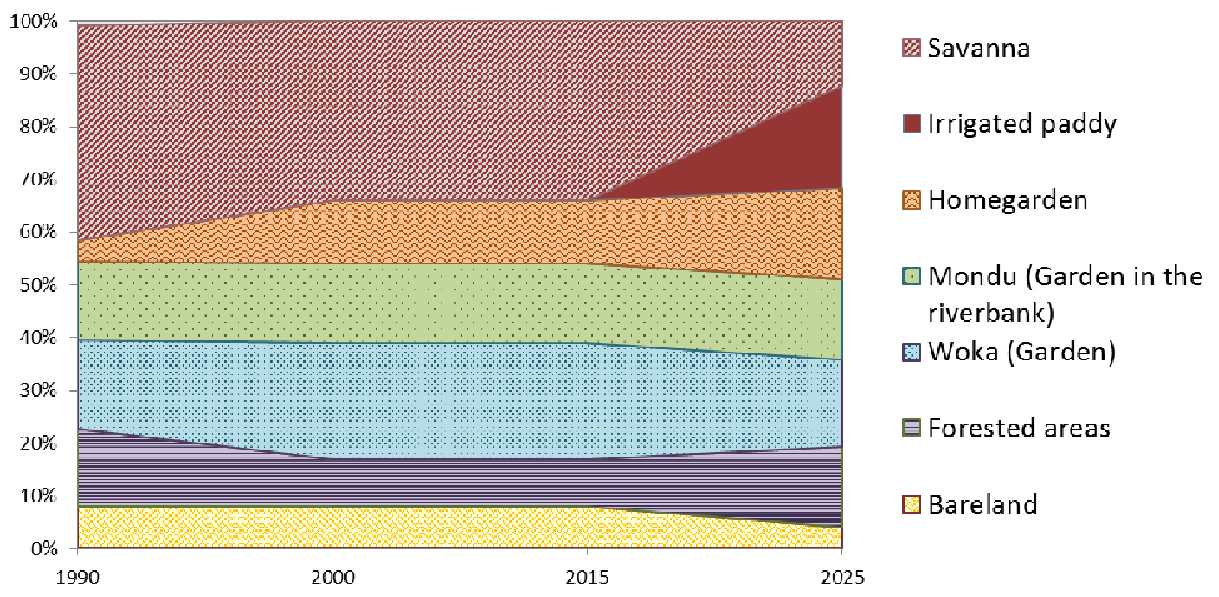

(B) Wunga

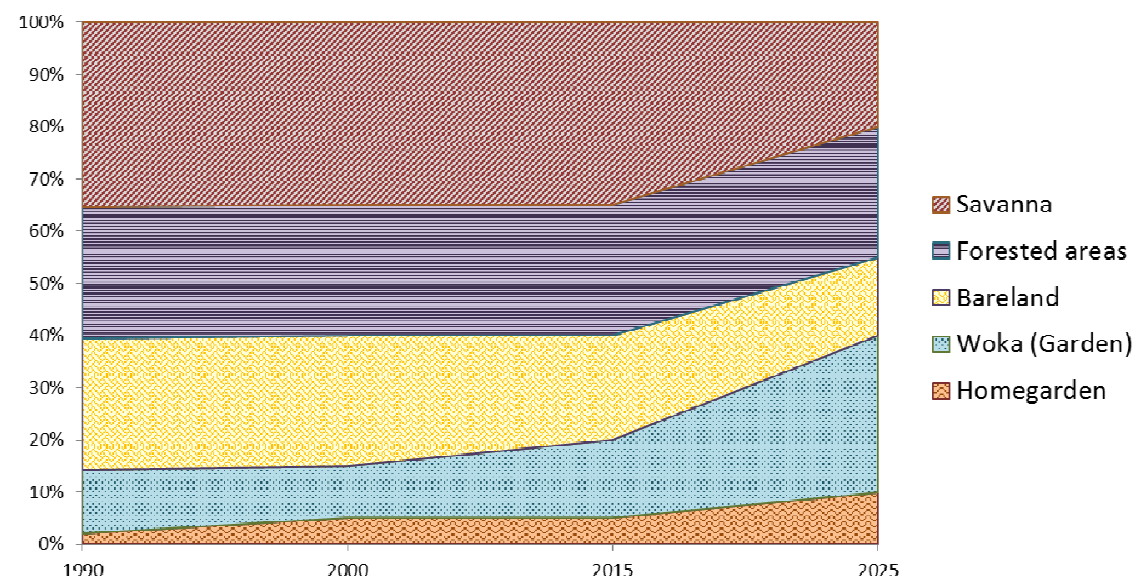




\section{(C) Kalamba}

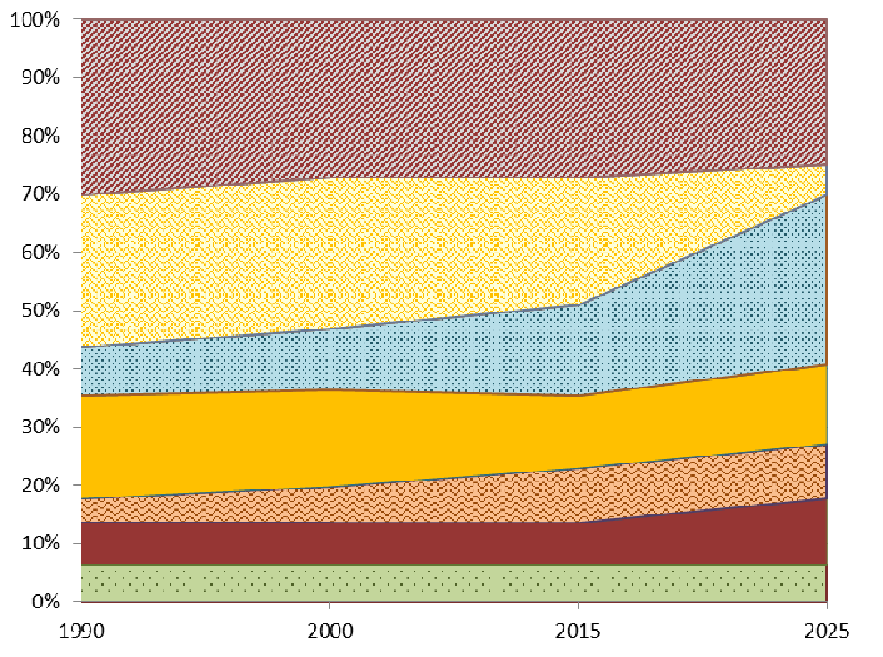

(D) Praibakul

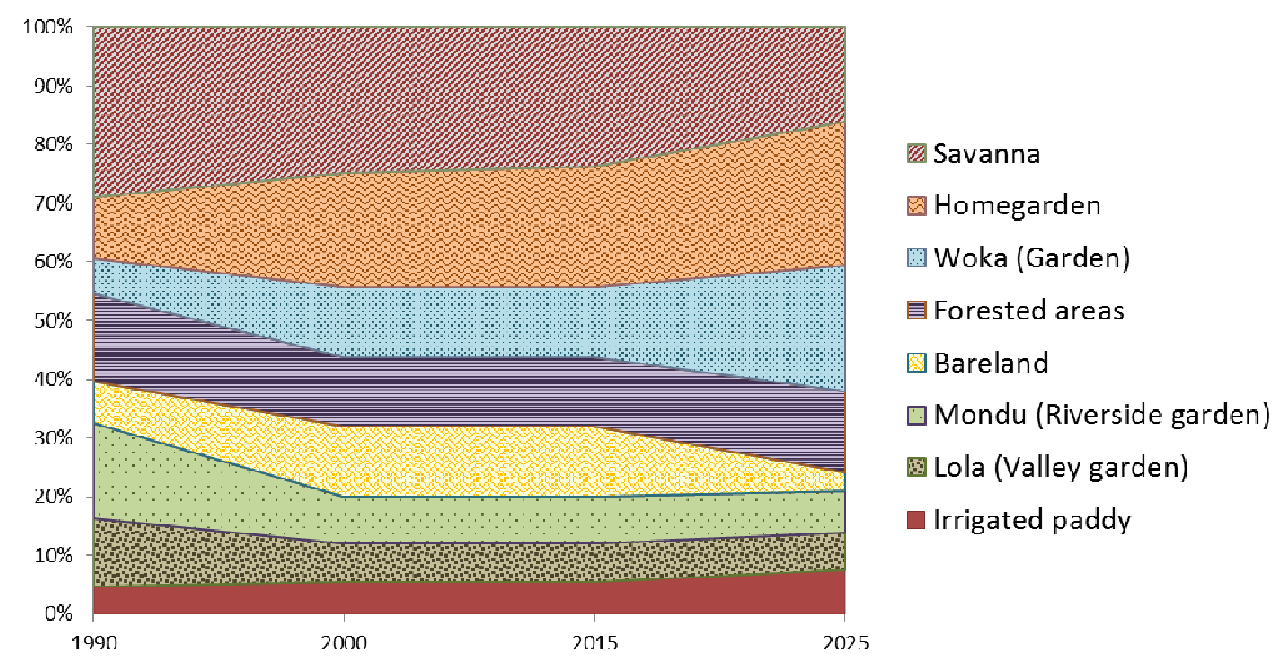

(E) Mbatapuhu

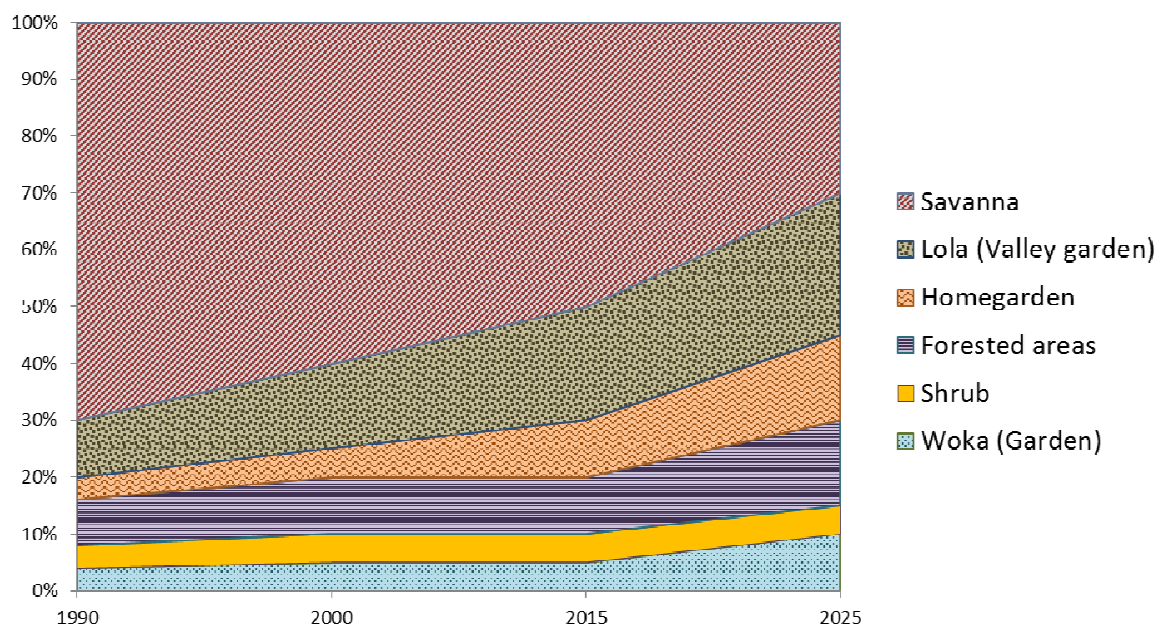

Figure 5. Land use changes from 1990 - 2025 based on farmers perception.

Data sources: focus group discussion

\section{圆 Savanna \\ Bareland \\ 国 Woka (Garden) \\ $\square$ Shrub \\ 圈 Homegarden \\ - Irrigated paddy}

$\square$ Mondu (Riverside garden)
앙 Lola (Valley garden)
ar Homegarden
Forested areas
Shrub
.: Woka (Garden) 
In 2025, people are expected to have more productive land such woka (garden) and lola (valley garden) that far from the house or woka uma (home garden). They are quite optimistic based on current situation, with some helps from National Non Government Organisations (WVI) based in Waingapu, they have community owned plots (demonstration plots), nutrition garden (kebun gizi), and raised bed farming. They plan to plant some more vegetation and trees in their land. However, we also noted some disagreement face from few discussant. They worried with the main problem in their villages, that is water availability. They contend that if they have not enough water, how they can manage the land. The second problem is the availability of good planting materials, they have not enough knowledge on this. Seems, that some mentoring on producing good planting materials is necessary, also improving people knowledge on how to be better management on rainwater harvesting or water protection.

Some villagers argue that forested areas will not change much, they contend the benefit from forest areas is not commensurate with the difficulties on how to exploit the forest, so they may not do nothing with the forest. The other villagers contend that the forested areas will increase, because they already have strong effort to plant the trees and do the 'palotang (pruning)' with support from the National NGOs based in Waingapu. No villagers indicate the forest areas is decreasing to add more some productive land. Seems, they commit to protect forested areas as it very scarce in this areas, and instead of converting forest, they plan to convert the bareland or savana to be more productive land. Though, in reality with the condition of the grassland ecosystem in Sumba which has quite a lot of rock/stone, the areas that may suitable for farming areas is quiet limited.

\section{Livelihood sources dynamics}

The livelihood source of people living in Haharu sub-district mostly relied on farming activities and raising livestock. Farming activities to fulfil their subsistence need, as well as small livestock as chicken and pig. Large livestock, such cattle and horse, were usually used for asset and customary purposes. Savanna, the vast landuse in their environment, such a benefit for livestock husbandry, though it also a challenge on doing better farming. Rocks and soil texture is quiet large spreaded in the landscape, and it makes the available farming areas is limited. People living in this areas need good knowledge on how to maintain the land better.

Livestock can be a symbol of social status of the family in Sumbanese family (Onvlee 1980, Melalatoa 1995). Livestock referes to the banda la marada or possesion in the field, and designated as banda luri or living goods or life property. The more live property (banda luri or livestock) you have, the higher social status you get.

Chicken owned by nearly $100 \%$ of household, except in Kadahang village. Each households at least have 3 - 10 chicken. Pig are also almost owned by $100 \%$ household, except in Kadahang and Napu, 
with $1-3$ pigs per household. Mbatapuhu is the village with higher percentage of pig ownership. The same as pigs and chickens, dog is also owned by majority household in each villages with $1-3$ dogs in each household. Since Kadahang is the poorest village, dog's owner is only about $90 \%$ of total villagers. In each villages, goat is usually owned by $50-70 \%$ household, with average per household is only $1-2$ goat. Many of them owned the goat through government program. Cow usually owned by $30 \%$ of the communities, while buffalo less than $15 \%$ of the community in each villages. People may upkeep cow and buffalo using scroll system, they feed the cattle until gets calves, and preserve the calves as theirs. After that, cattle raising turn to others. The scroll systems applied based on support of local government programs.

Horse may owned by high social status of people. Horse owner in Praibakul and Mbatapuhu covers half of the population, while in other villages, only less than 10\%. Praibakul and Mbatapuhu were known as the villages where social caste still strongly exist. Each horse owner household may owned $1-5$ horse. The same with cattle, people may get horse with 'borrowing scheme'. Borrower keeps and feed a pair of horses belongs to the owner up to twice foaling, after that, the horse and one of the foal was returned to the owner, and the other foal was taken by the borrower.

Most important commodity in farming activities of Sumbanese family is maize. Result of FGDs in each villages always performing that maize is an important source of food for people (subsistence), though it also can be marketed. Fowler (2005) describe on the importance of Maize for Kodi People living in western Sumba, as also can illustrate the situation in Haharu Sub-District where most of people perceived that maize is very important commoditiest to cultivate. If paddy is very expensive and laborous in production, in contrary, maize is easy to cultivate and also suitable with the soil condition in Sumba Timur. It can be planted anywhere, in riverside areas, in valley areas, as well as in highland areas.

Aside from Maize, sumbanese family also cultivating sorgum (Sorghum bicolor L.) or locally called as Jagung Rote or Cantel (Javanese). Sorgum or Jagung rote is a crop being developed by the government on a large scale, and NTT provinces became one of the areas most suitable for this crop. Sorghum is a native species has been known many years ago, but then increasingly marginalized, due to the low preferences in compare to rice and maize. One of the distinctive properties of sorghum is resistance to drought, acid soil, and high salinity, therefore it suitable for the marginal land as in Sumba Timur. Sorghum is also have good resistency to pests and diseases and high tolerant to waterlogging. Nowadays, people just utilize the seed as food sources, other potential as roots, leaves, and stalks only useful for fodder and compost.

When severe food shortage happen, people are usually began to consume wild parsnip (ubi hutan or sikapa or iwi, latin names Dioscorea hispida Dennst.). The parsnip is easily grown in every condition and can be found in forested areas. Though it's poisonous, but due to no other alternative, people are still consume this with good processing. The benefit of cultivating the parsnip, it has high resistency to drought, and easily to cultivate. 
Nutritious garden was mentioned as one of important livelihood sources, mainly for subsistence needs. Initiative of nutritious garden were from the national NGOs based in Waingapu who have almost 10 years side by side with the sumba people in Haharu develop their villages. Nutritious garden is an important land use for women, because they are the one who responsible to maintain it. Location of nutritious garden were in Woka Lola, Woka Mondu, and few of them in Woka Uma. Thats also the land use where usually women do the farming practices with their husband and other family members.

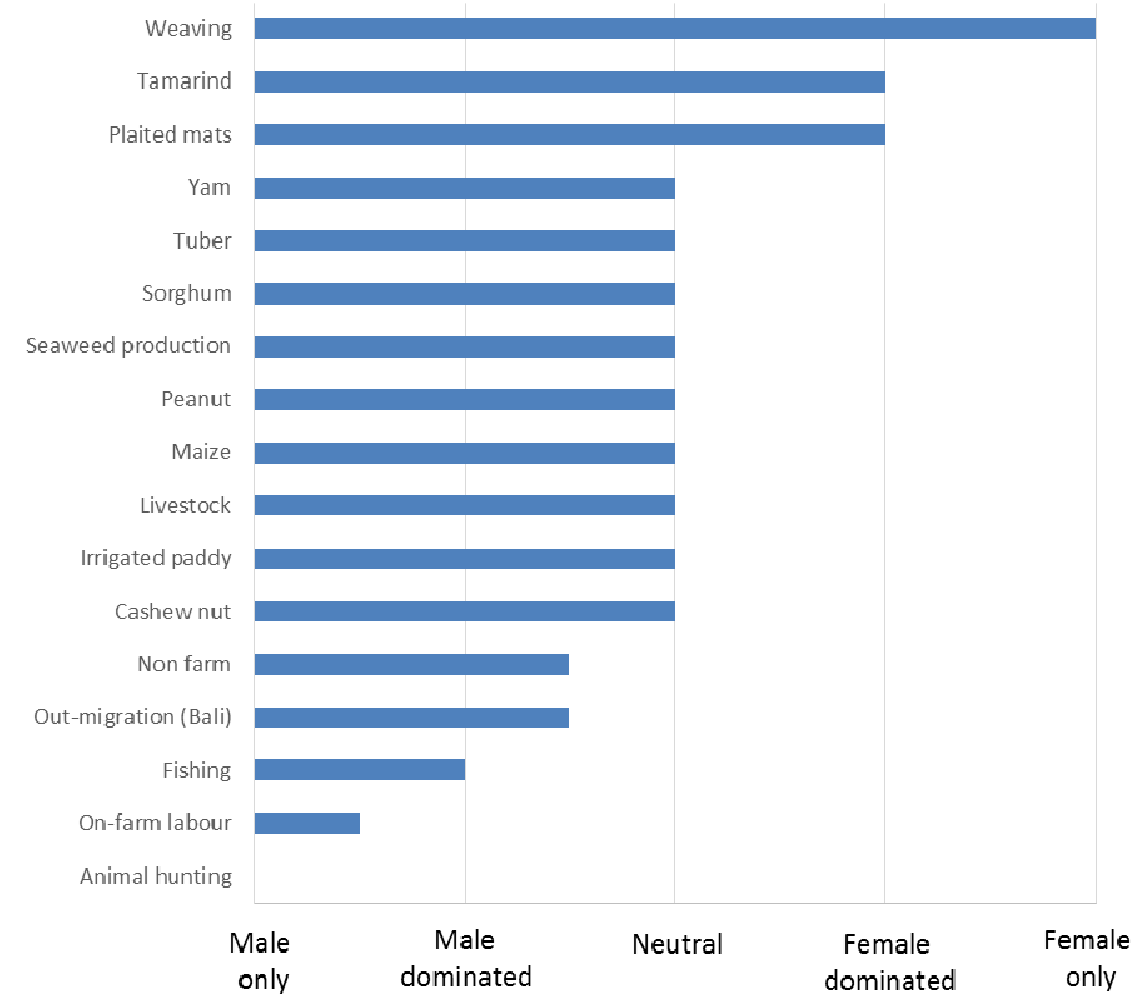

Figure 6. Source of important livelihoods and women involvement in each activities.

Data source: group discussions

For people in Wunga, Napu, Kadahang and Rambangaru, fishing is also an important livelihood sources. Palekahelu (2010) describe that in Wunga, aside from farming in dryland areas, men are usually go to the sea to catch fish and produce is become salty fish. Women's are usually in search and collect of trepang or sea slug for delicacy and it's also marketable. Women and men are working together producing salt and salty fish.

Rambangaru and Praibakul become the most important centre of peanut production in Haharu Subdistrict. In 2013, production of peanut is 106 ton and 102 ton in Rambangaru and Praibakul respectively, and both are covers for about 84\% from total production in Haharu Sub-district (246 ton). Peanut is planted in woka, and it can be in any kind of soil condition, in valley areas, in riverside, 
as well as in highland areas. Men and women are working together in planting and harvesting peanut, while on maintenance it usually done by men, who more often go to the field.

Some of Kalamba people planted kacang turis or known as kacang gude (Cajanus cajan), in Africa it known as congo pea, and internationally known as pigeon pea. In Indonesia, 'kacang gude' were planted in the island of Java, Bali, East Nusa Tenggara, South Sulawesi and Southeast Sulawesi (Wakatobi). In East Java, kacang gude cultivation in dried highland areas (2000 asl), while in eastern part of Indonesia, it can be planted in any kind of areas. As shrubs, kacang turis can live in a variety of soil conditions, height can reach 1-2 meters. People may utilize the seed and the leaves for consumption, and also has high quality of manure materials.

Imperata cylindrica is useful as thatch roof for traditional house of sumba people. People were harvesting imperata reeds and selling it in local market as raw materials for roof. Cutting the reeds become important livelihood source to get cash income or for barter. Both men and women are involved in this type of activities.

In Local Regulation of Sumba Timur, No 12 Years 2010, about Regional Spatial Plan for Sumba Timur District year of 2008-2028, Haharu sub-district were assigned as rice development centers. Though in reality, irrigated paddy rice become an important source of livelihood only for few peoples in Rambangaru, Praibakul and Kalamba. In 2014, there were 9 ha and 5 ha of paddy field in Rambangaru and Praibakul respectively, with total production is about 62.5 tonne and 19.14 tonne per year (Haharu in Figures, 2015).

In the household with limited land or less land for farming production, out-migration to Bali be an important alternative livelihood source. Migratory activity is typically performed in a number of villages such as Napu and Kadahang. The group that migrated mostly young men, both men and women with the aim of working as tourist guides or waiters at the boutiques, shops, etc. It is interesting to know why the out-migration case is only found in Napu and Kadahang villages, and not in the other villages.

Haharu sub-district play an important role as the hinterland in the seaweed (Eucheuma cottonii), minapolis areas, in particular in Wunga, Kadahang, Rambangaru dan Napu villages. This is formally stated in Decision Letter of Sumba Timur head of District (Bupati) No:

204/Dis. PKL.523.3/1.169/XI/2010. Initiation of seaweed production were in year of 2001. Short rainfall periods ( 8 - 9 months of dry season and $3-4$ months of wet season) be a benefit of production process and harvesting of seaweed. 
(A) Kadahang

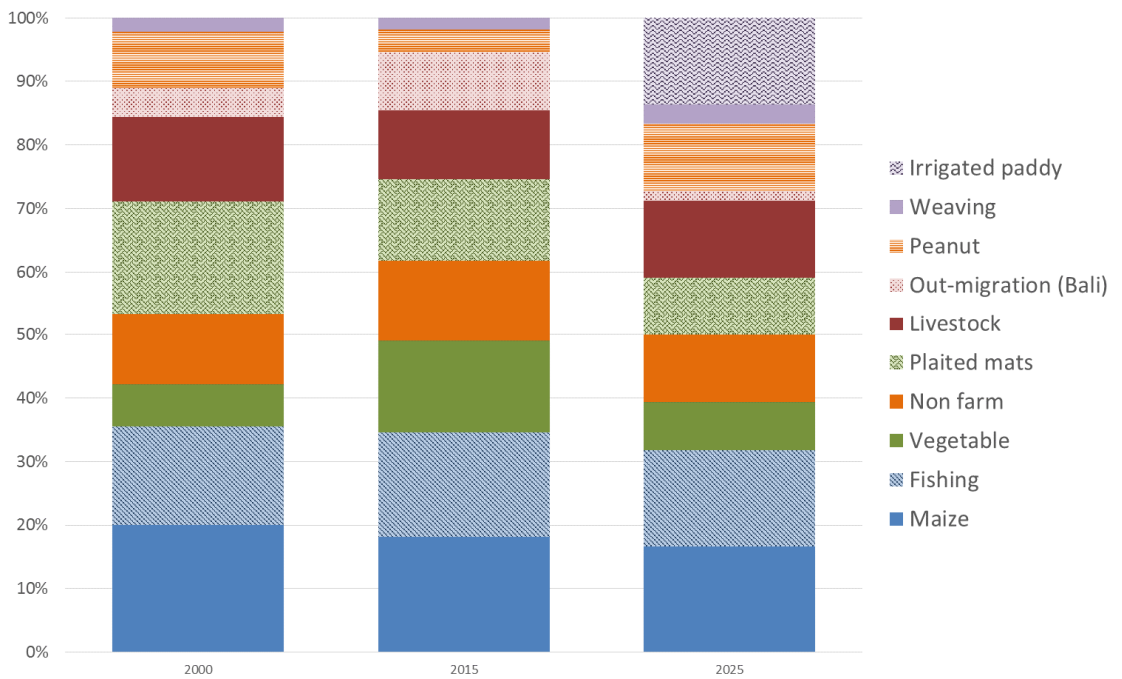

(B) Wunga

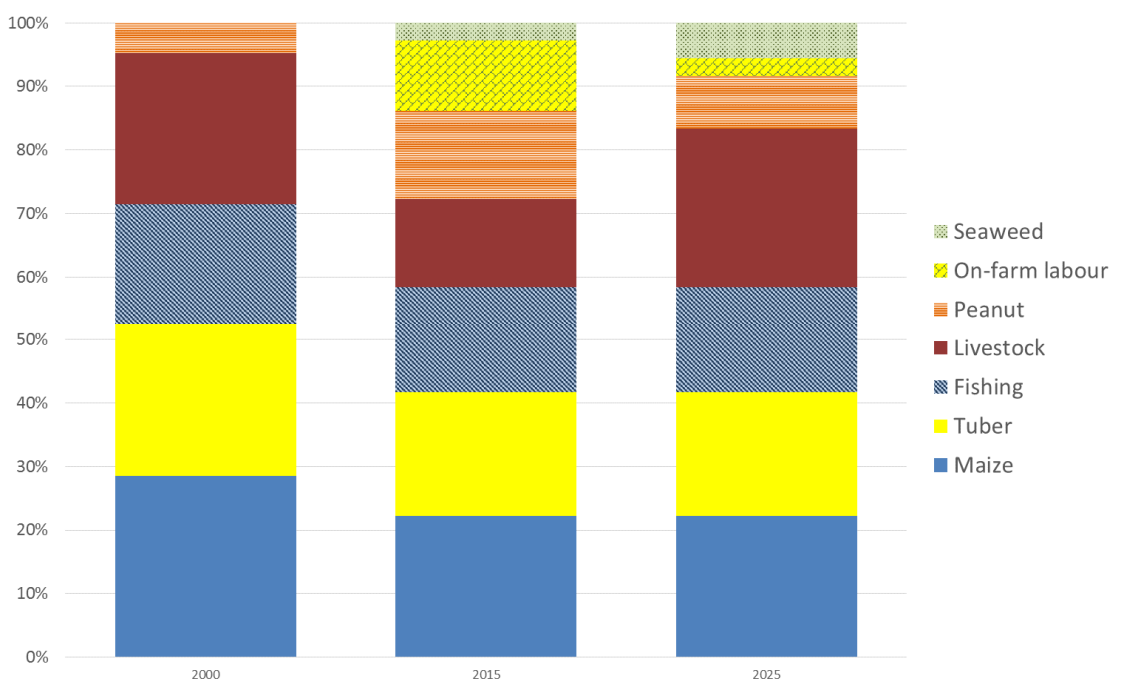

(C) Kalamba

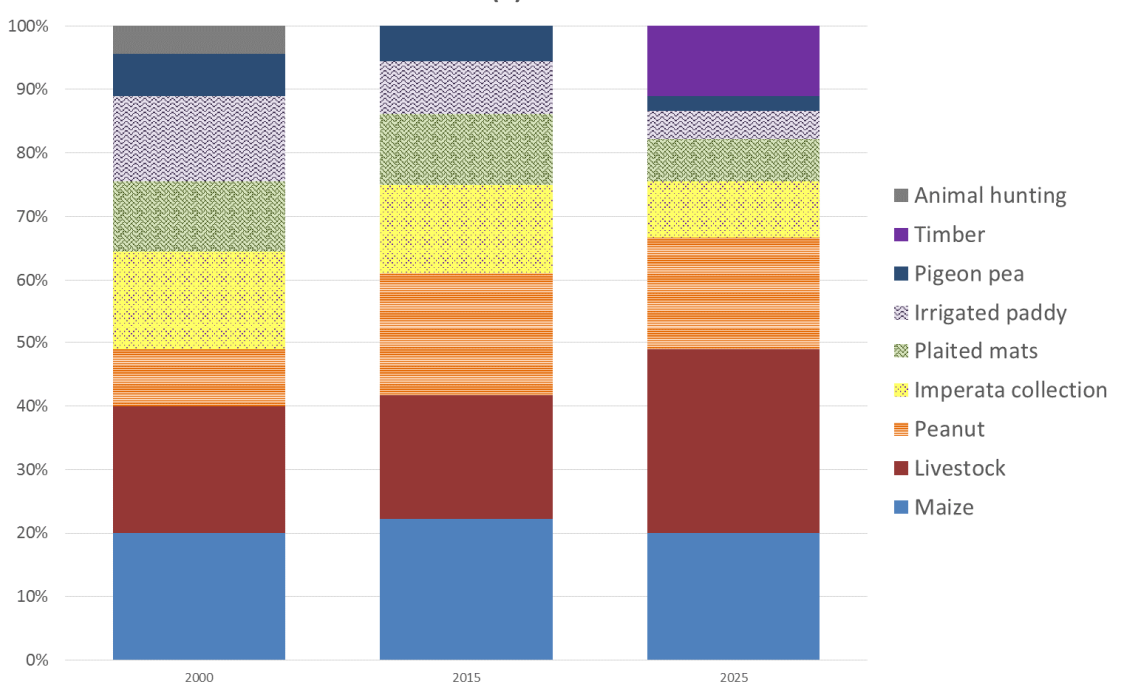


(D) Praibakul

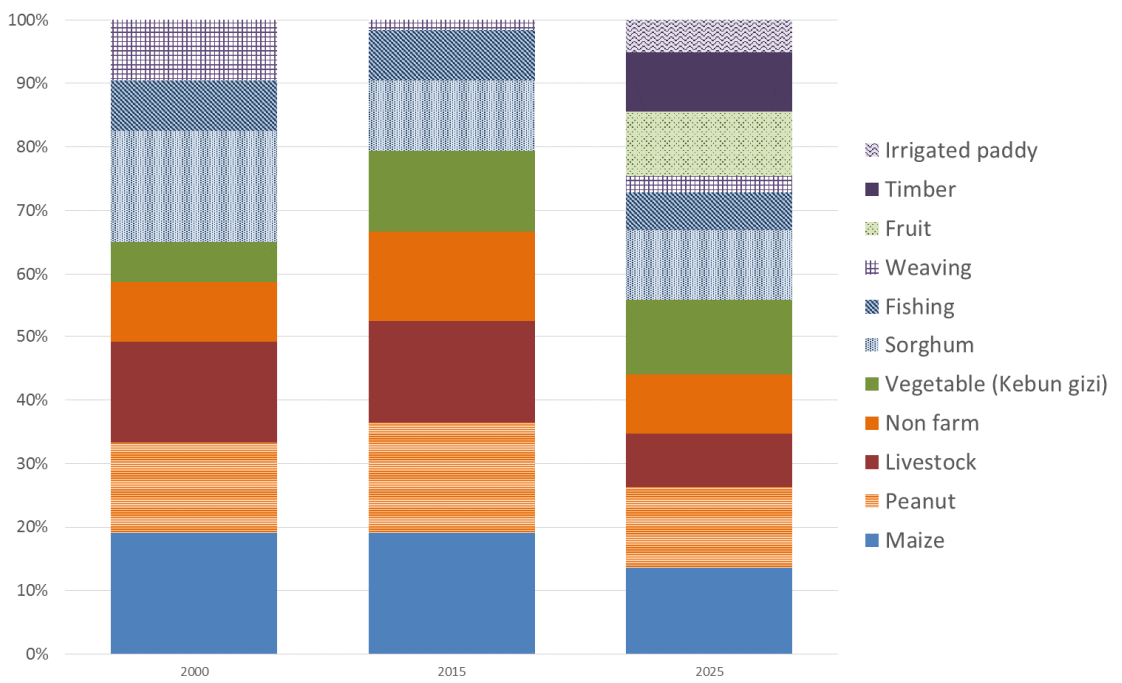

(E) Mbatapuhu
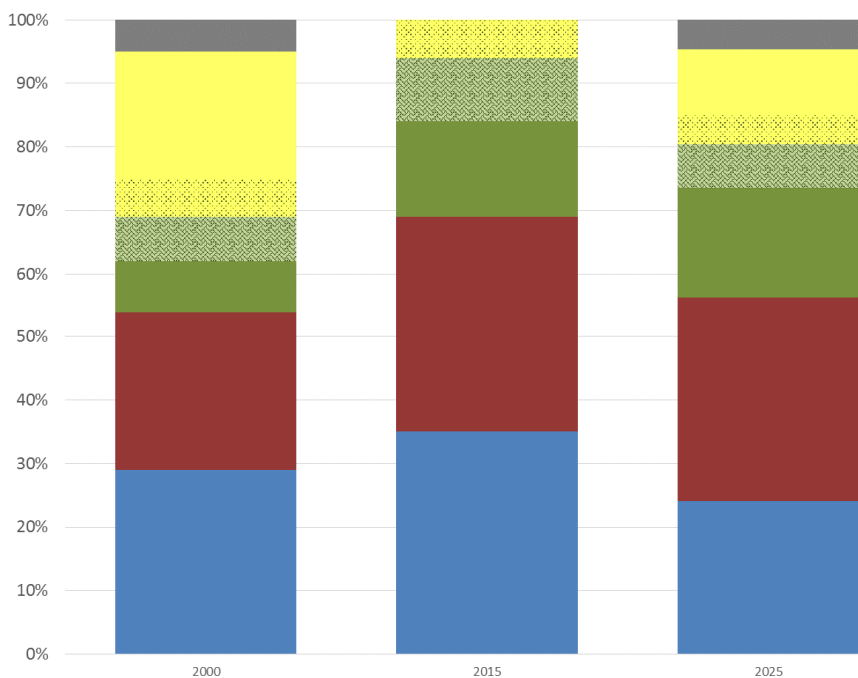

Animal hunting

Yam

. Imperata

Plaited mats

- Vegetable

- Livestock

naize

Figure 7. Change of livelihood sources in two different periods and the projection livelihood sources in the future.

Data Source: Focus group discussion

\section{Division of work in household and productive activities}

\section{In household and farming activities}

Men and women have different task and responsibility in household task and farming activities and its complementary. While men usually more responsible on farming activities, women's responsibility more on the household task. Figure 8 illustrating the roles of men and women in each task in household and some farming activities. Men dominating the work related to opening the new land and also do the mandara (looking for material support from the extend family). Opening the new land, due to heavy work, it is usually dominated by men, and the men also become the one who make 
decision where and when the best time to open the land, including if they need to hire or add additional labor.

Build the house is mostly under men responsibility. Palotang (pruning, under farmer manage natural regeneration or FMNR program by WVI, national NGOs based in Waingapu), is the activity can be done by both men or women, though usually the role of men is bigger. Selling farming and livestock products, purchasing farming and livestock input and also household things were mostly become join work and join decision making of men and women. Men and women have almost the same proportion of role on this. On the decision making process, men usually asked women before they make decision. Interestingly, in term of land management, aside land management and palotang or pruning the natural regeneration plants, women have bigger role in compare to the men. Women's role are also essential in household financing administrative, as well as make sure all the household members have consume a dietary food.

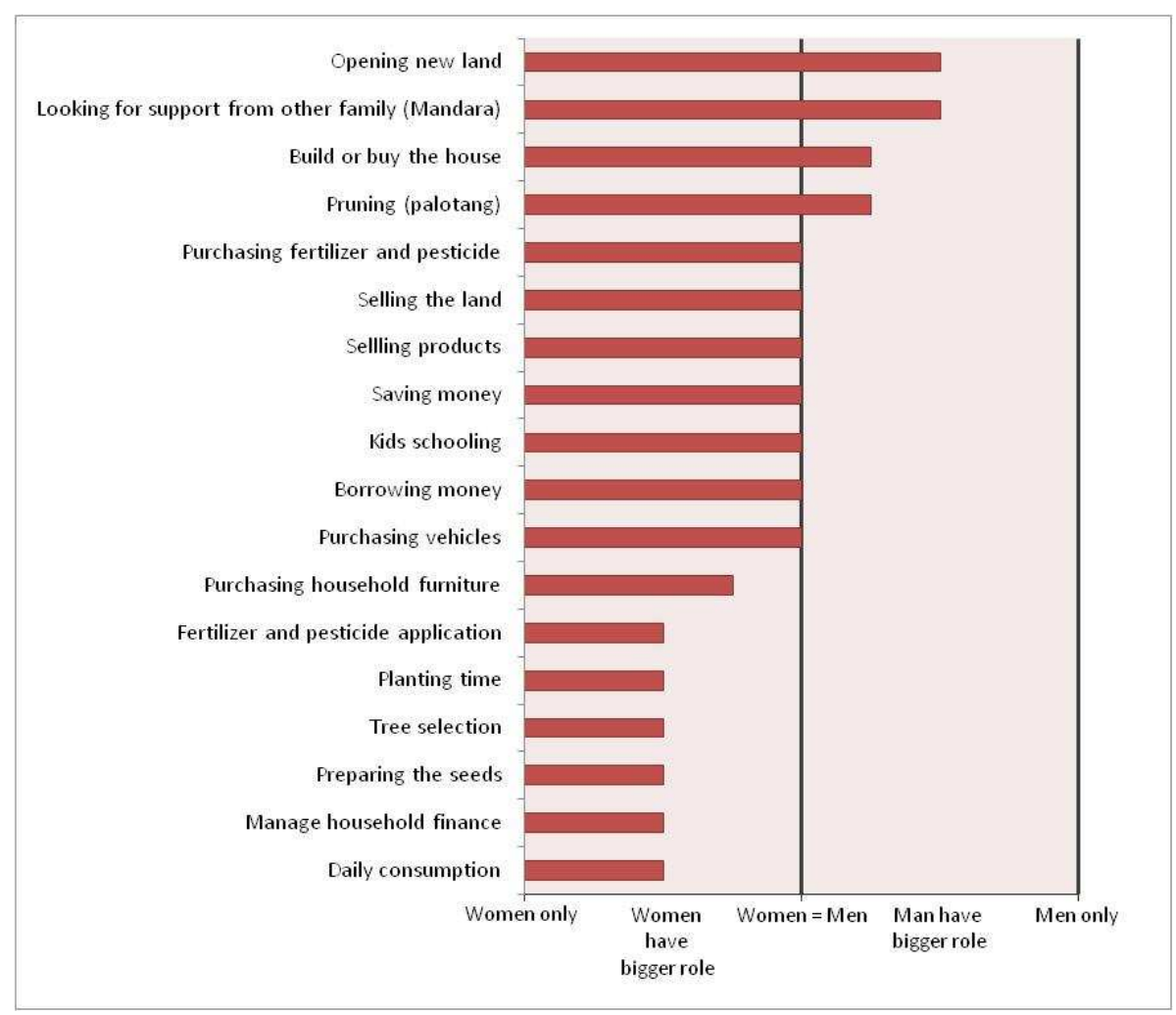

Figure 8. Gendered role on basic activities in household and farming practices

\section{In farming practices}

Role of gender in farming practices were simply just the same as in any other areas in Indonesia, though the difference is also seen in two different land location. Men are usually have higher role in land preparation, both in the land areas that near from the house in highland or inland area (Woka) as 
well as in land areas in the valley (Lola) (Figure 9). Planting and harvesting in both woka and lola dominated by women ( $58 \%$ and $65 \%$ respectively). This is mostly happened in anywhere, any places in Indonesia. Planting and harvesting is labourous work, therefore men and women are usually working together to ease and fasten the process. Post harvest processing were usually done together. Farming maintenance in Lola were dominated by men (63\%), due to the distance and difficulties to reach the location, while in woka, though men still dominated, however, women's involvement is a bit higher (48\%).

Selling the products and nursery production in Woka (near the house) were dominated by women, while in Lola (the valley), women's work are more less the same as the men's. The frequent of women go to the valley is less than the men, due to their responsible in the house, therefore women's work focus on the laborous work. Work that related to selling and preparing nursery become the less priority of women. However, overall, women involvement in farming practices in woka is $51 \%$ while in lola is $49 \%$. Still, women's contribution to the farming practices is relatively high.

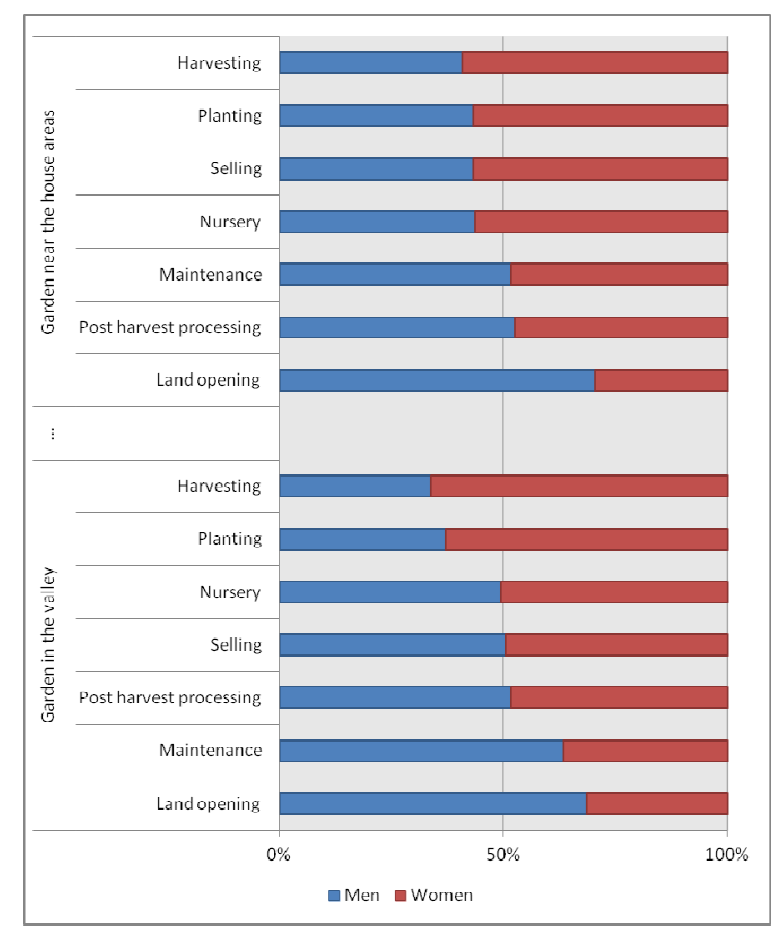

Figure 9. Gendered roles in farming practices

\section{Animal husbandry}

In Sumba, animal is the important assets in each household. Cattle, horse and pig have strong cultural value, as belis or dowry. Chicken is mainly for food security, while dog is for the guardian and hunting companion. The importance of cattle depends on the social status of the owner (Fox 1980). If we compare all of the figure in Figure 10, Figure 11, and Figure 12, we might see that division of work in pig husbandry were luminous in compare to other animal husbandry. The proportion of 
men's role in pig raising is $50 \%$. The graphs also shows that perception of men and women in term of pig husbandry is not so different, men and women almost have the same perception. It is clear that feeding, provide water and clean the dung were become the main responsibility of women, while men more responsible on selling the animal or the products of the animal and the heavy task as build the stall for the animals.

Raising cattle were usually done by men (56\%), with main responsibility in build stalling and selling the cattle when necessary. Women's role on cattle husbandry mainly on feeding and clean the animal dung. Almost the same as in pig husbandry, women's involvement in selling the cattle and its products were smaller than man, also in build animal stall. Gendered division of task in horse husbandry were showing almost similar pattern as cattle husbandry. Woman have slightly higher responsibility in grazing, binding the animal, provide water and the santitation. However, degree of answer variety between men and women about gendered roles in pig husbandry is moderately lower than in the other two animal husbandry types. We would say that division of task between men and women are more clear, and both men and women are have almost the same opinion on this.

In horse husbandry, taming the animal is only by men due to the hard skill and also considering the safety. Taming the horse is very important work to do, especially long time ago, when the horse is very useful as the ride or the transportation media. Currently, horse still important in pasola festival (ceremony of a gratitude to the ancestral) and as dowry, as well as it has high social status.

Interesting story from Kalamba village on grazing the animals that different from the other villages. Due to the topography condition of Kalamba that like living in couldron, as well as river strategic position within the village, the Kalamba people have a good sytem of herding cattle. They use rolling systems with some of cattle owner. There were two or three cattle owner have a duty to herd their cattle in a week. The next week, the herders replaced by other person (the other cattle owner, or someone that specifically paid as herderes). The people on duty of herd will be free from the other duty in the community. For example, they allowed for not attending the burial process, or any work together (gotong royong), and other duty in the village. If there were a relief programme or rice ditribution, their share will be saved by their colleagues or the spouse who are not in herd duty. People of Kalamba also has separate grazing areas, so their garden is safe from the animals. Interestingly, in Kalamba, the garden areas, is not using the stone fence nor tree fence for protection. 


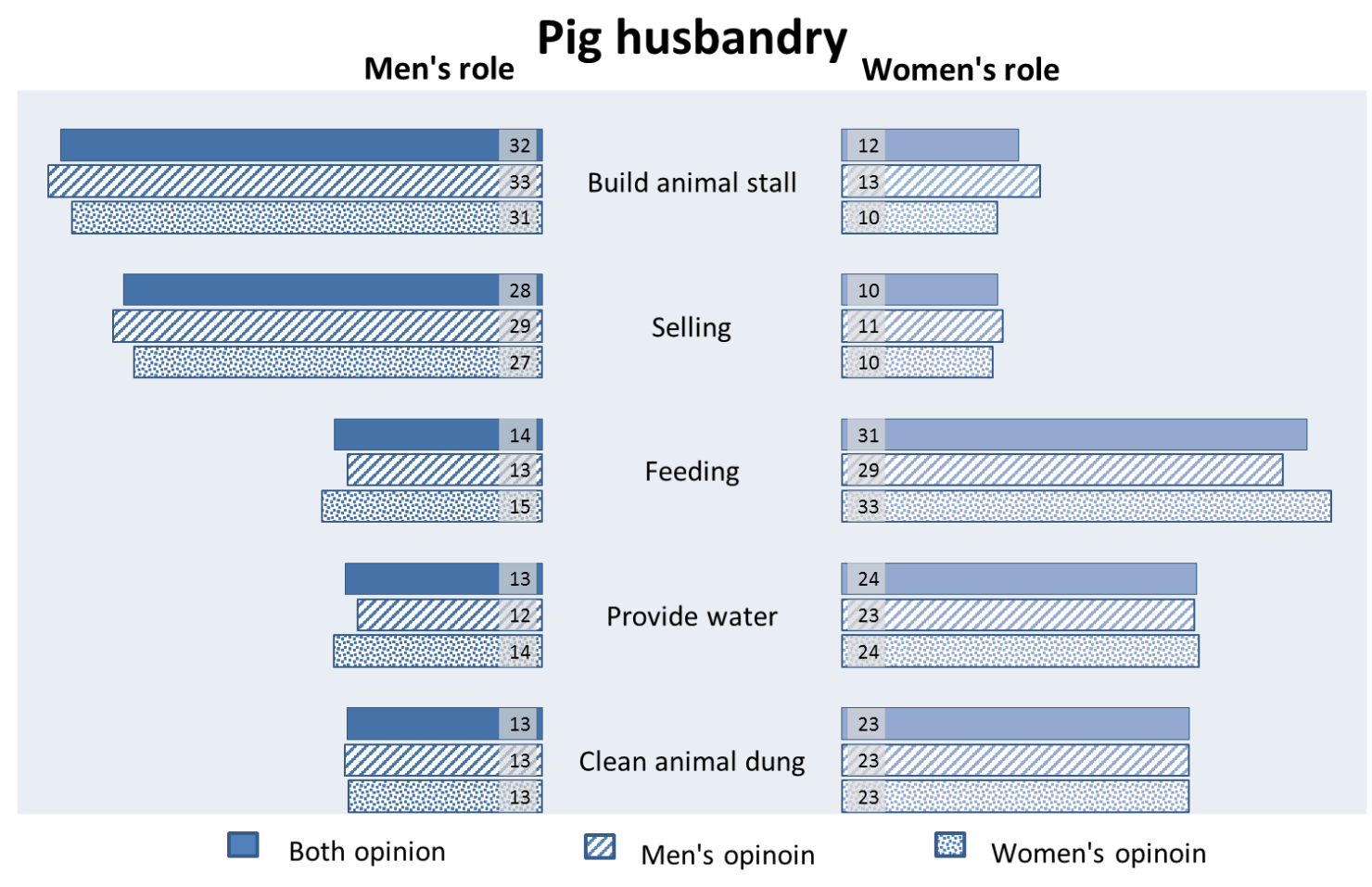

Figure 10. Division of role in pig husbandry

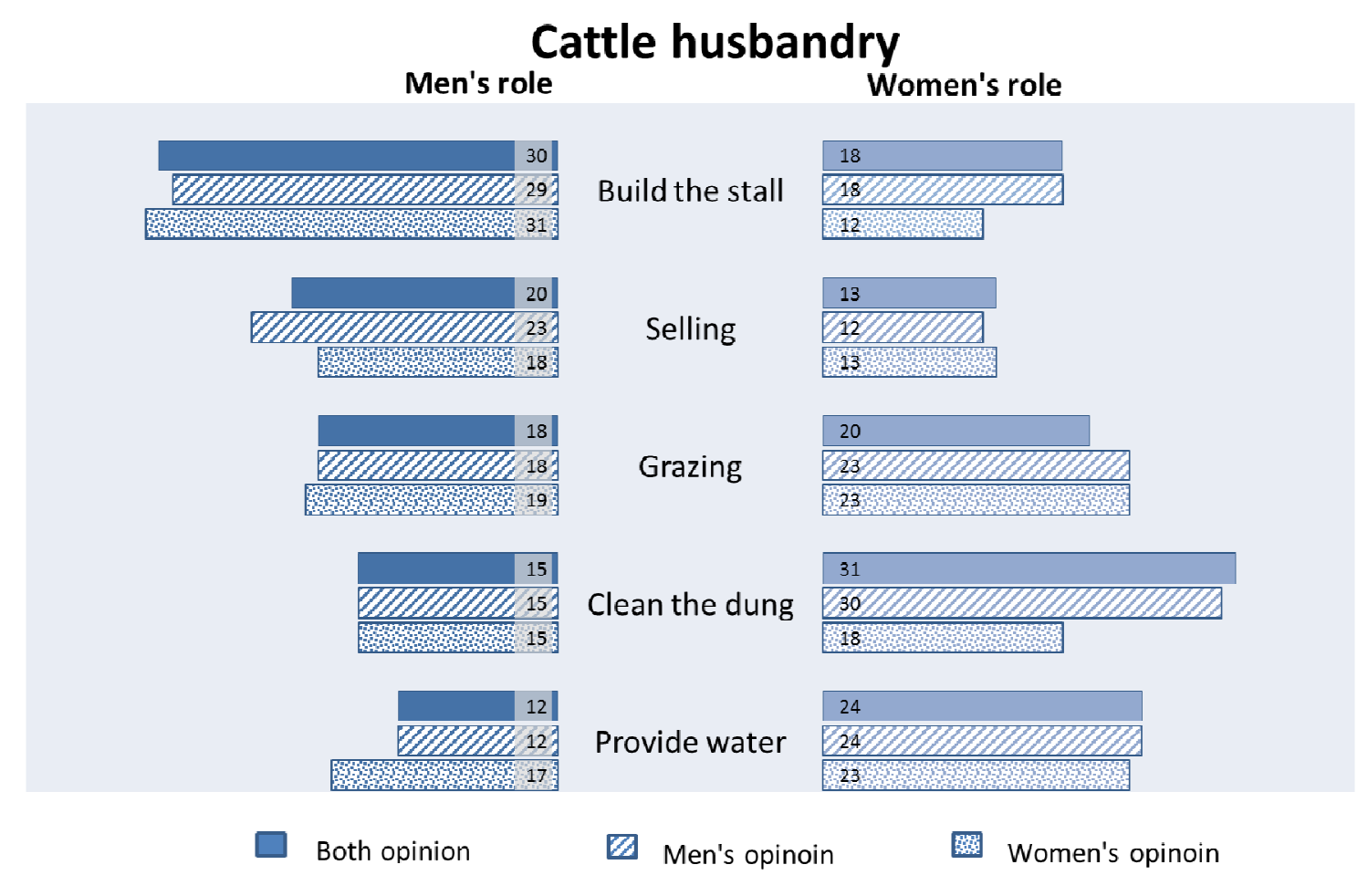

Figure 11. Division of role on cattle husbandry 


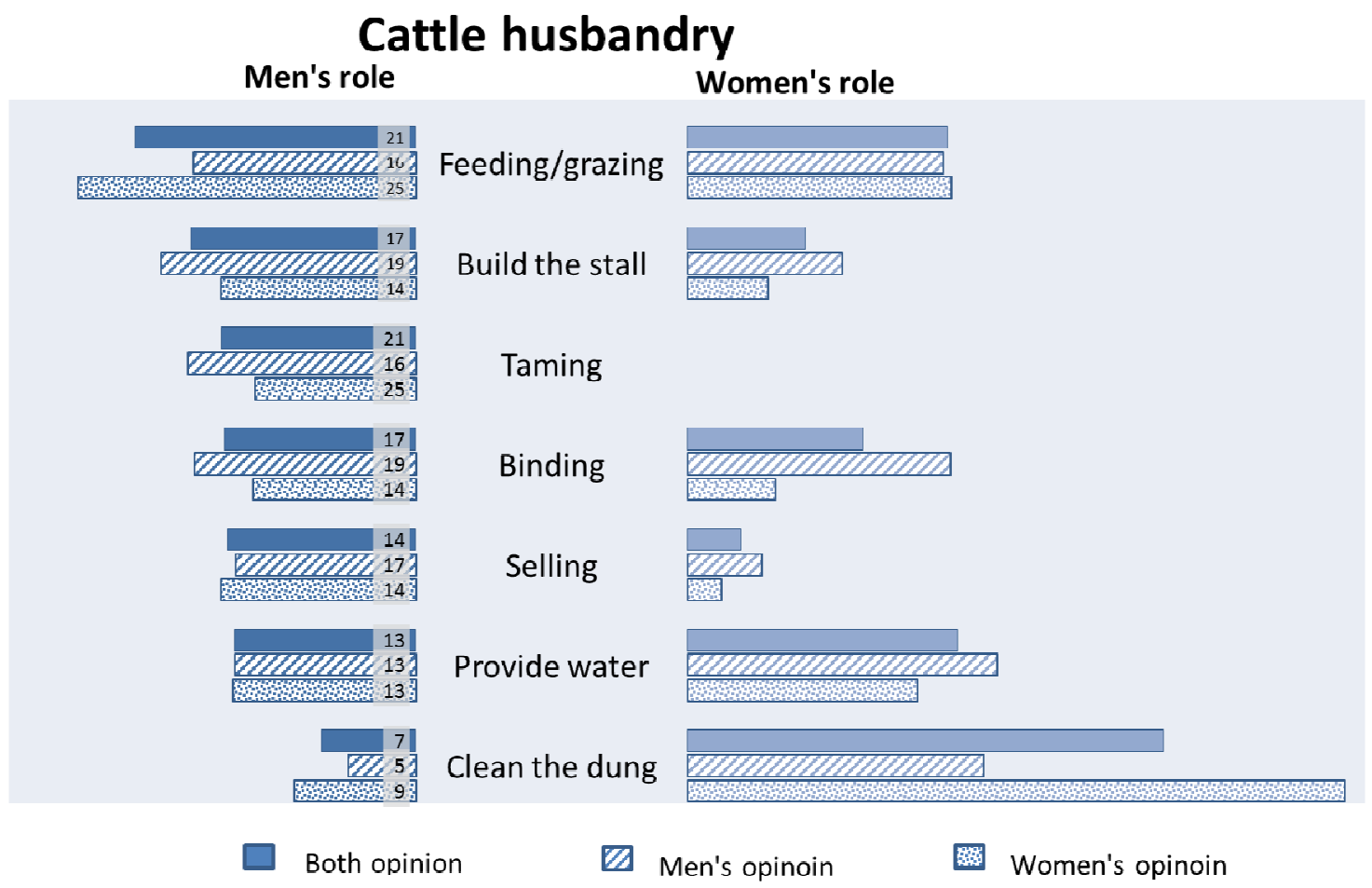

Figure 12. Division of role on horse husbandry

\section{Water tapping}

Water is very crucial for all human being, and in Sumba water is very scarces. As indicated above, women have big responsibiliy to find water to fulfil household needs, for human consumption as well as for the animals. People may get clean water for drinking and cooking from the nearest water sources. Wunga and Mbatapuhu village is the most severe village in term of water issues. Many of the community living in those villages need to go to the nearest source of water by walking for almost 2 hours with the steep road and its usually located in ravine (lindi). Some of them try to find water that trapped in rock crevice (way kulup), and if its has good quality they may consume it, but if its not, it is just for the animal. While for farming practices, aside from the land areas that near to the river or other water sources, they rely on the rainfall. For body sanitation, they may go to the nearest rivers once per week to have proper shower and washing the clothes. Figure 13 shows the old women collect water for animals from the rock crevices. In Wunga, there is also brackish water lake which can be used as an alternative source of water. Some of the community have already supported by the government, NGOS, and other organization to build rainwater storage (both on the rooftop or tanki/locally called as fiber) that can be used for household consumption and farming activities.

In household, the task to tap water, is not mainly become women responsibility, it is join responsibility. Though in reality, usually women go to the water source because they need to clean them self as well as washing the clothes, the dishes, and use the water for cooking. A woman may carry 1 bucket (15 litre) and 1 jerry can (5 litre), and/or the clothes that they need to wash. During 
rainy season, women may save more time not to go to the water source, they rely on water in rainy water storage near the house areas.

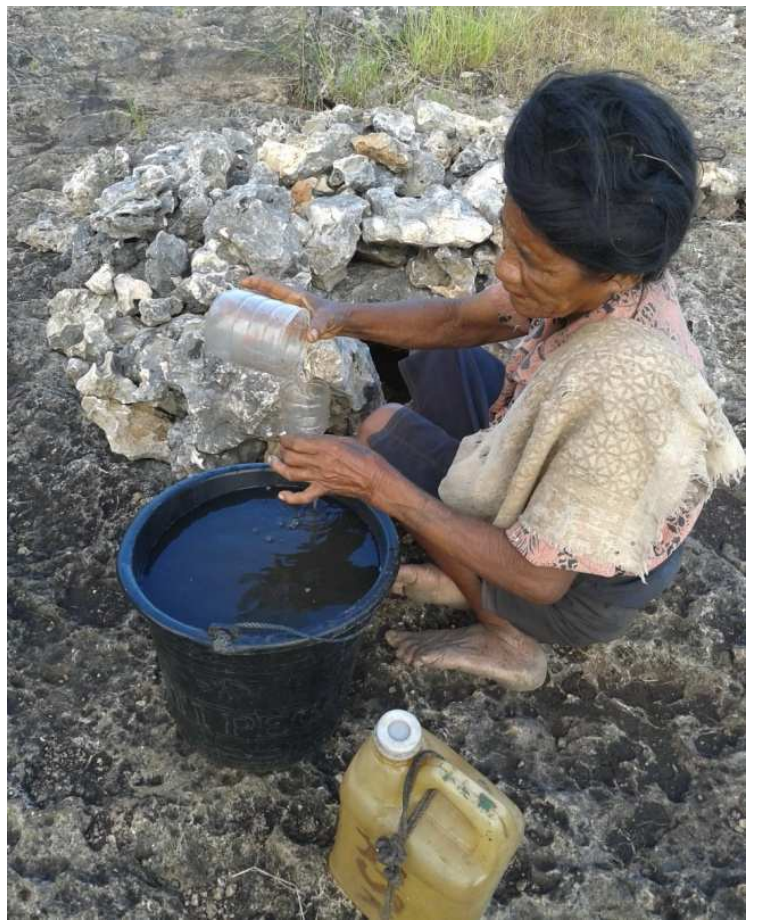

Figure 13. Old women tapping rain water from the stone

\section{Gendered knowledge and perception}

Different perception of men and women in valuing each land use systems were captured from series of focus group discussion. The group discussion were implemented in each village by using analytical hierarchical process. The first step, discussion participant mention some of the land use existing in each villages, then we discuss which are the land use as their priority location to plant the new trees or other vegetation for restoration purposes. Separate discussion between men and women allow us to get different perspective of men and women.

Figure 14 shows the results of the analysis on the land use priority where to plant more trees for restoration that may fit with their household needs and their potentiality to maintain the plot were captured in the FGDs in most of the surveyed villages. The figure divided to 4 quadrant. The bubbles that falls in this quadrant are the land use bubbles that prioritized by both men and women for planting more trees in term of reforestation process. The bubbles in quadrant 2 were the land use more prefered by the man, women's high preferences in quadrant 4 . Quadrant 3 were the location of the bubbles with low preferences by both men and women.

There were no significance differents view between men and women (tested by Mann-Whitney). Both men and women are agree that the areas good for reforestation is their garden areas, in particular garden that near from the house. The consideration is not on the environmental function, but on how 
they could manage the land efficient and more effective. Planting more trees near their housing areas is less laborous. Moreover, planting more trees in their current productive land will also less capital needed. The second priority is on the bareland. For men's, planting in the bareland can improve the soil condition and also make their bareland become more productive. They also mention about the division of task, if the men focus on the bareland, then women can be more responsible in the garden that near to the house. While women's, although many of them were not fully agree on this, arguing that planting in the bareland will give them any additional income. Here we might see slight different opinion between men and women. Men's opinion were usually based on the needs to expand the land, while women more on economic issues.

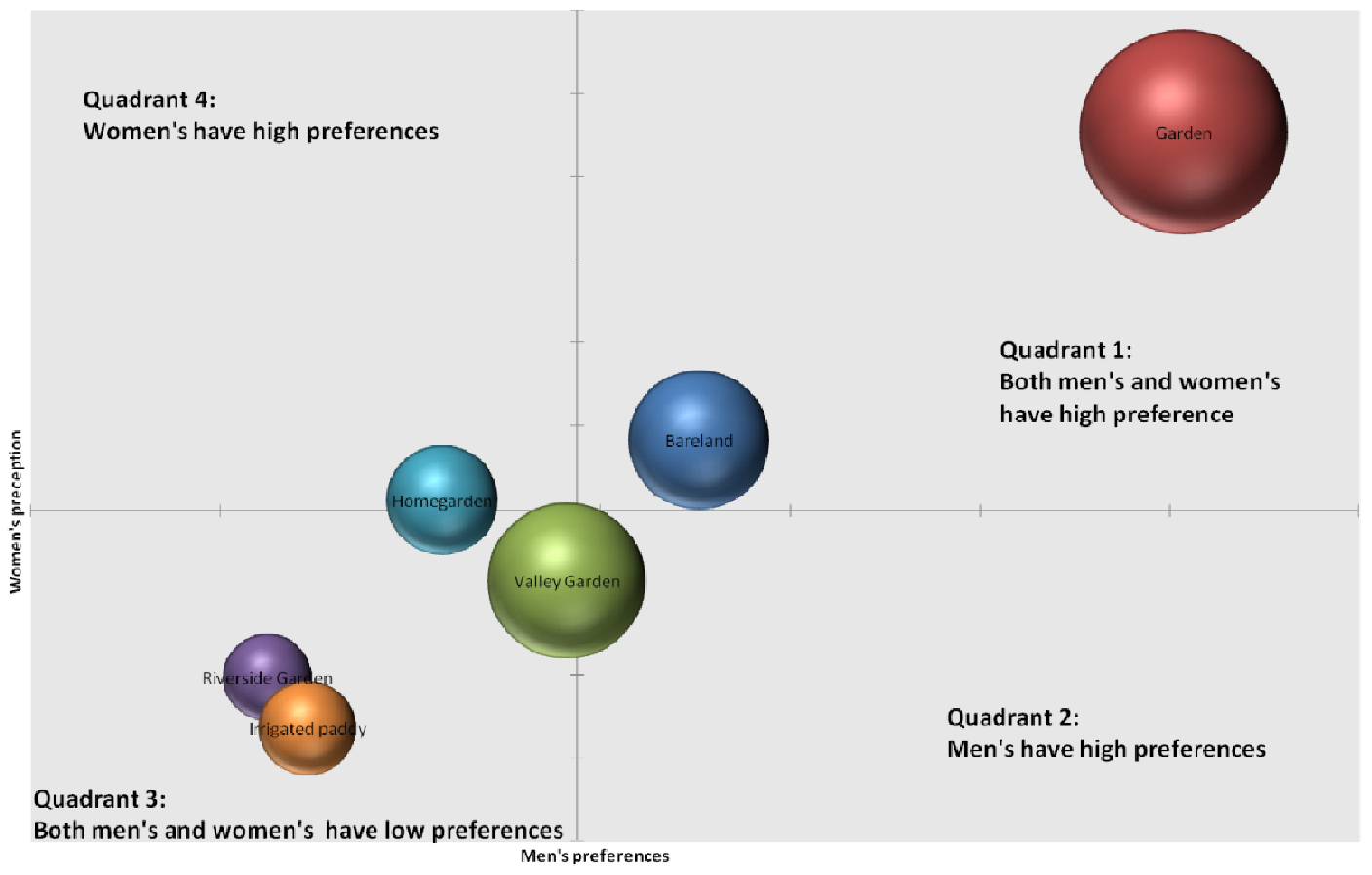

Figure 14. Gendered preferences on land

In term of fire causing factors, we also tried to differentiate opinion between men and women. The result (as presented in Figure 15), shows that no signicifant difference perception between men and women. Both men and women perceived that human error factors is the most often happen in fire incidence in Haharu areas. Savana in dry season were very fire prone situation, but people are usually not really careful, they just throw out the cigarette with fire in anywhere. For men, bird hunting were become the second factor causing fire, while women mention that deer hunting and grass rejuvenation (people are usually deliberately fire the grass for rejuvenation, but then become uncontrolled and causing severe fires). Land opening become the last factor that causing fires. 


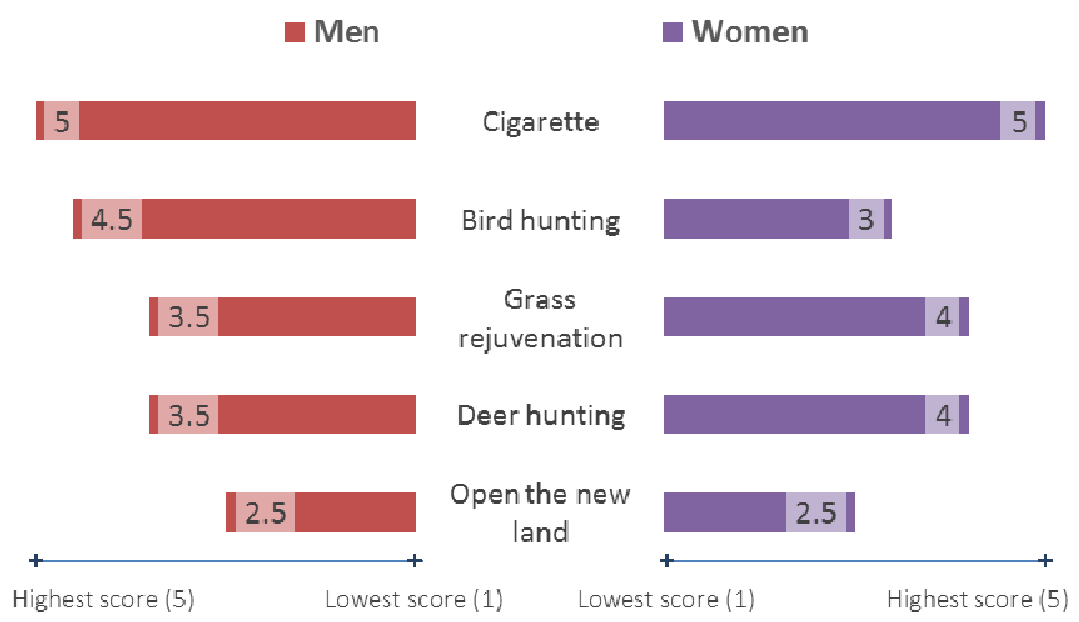

Figure 15. Gendered perception on fire causal factors. Numbers in the bars indicate the median score from all of the discussion numbers in each villages. Data source: focus group discussions.

\section{Men and women: how they involve in grassland restoration?}

From all the information that we gathered and we presented in earlier part of this working paper, we might see that women and men have almost the same contribution in farming, animal husbandry, and tapping watter as one of productive work in each household, while women have also other responsibility in the house for cleaning, cooking, and take care the kids. Fowler (2012) on her ethnographs in Kodi community, perceived that division of work of Sumba people appears relatively egalitarian and complementary between men and women. However, this research perceived that women still have more burden in compare to the men, they have more responsibility, in particular in household activities.

Nurdiah et al (2015) perceived that based on gendered space analysis in Sumba Timur, in term of domestic life, relation of men and women were also equal, both men and women were have adequate space though the location might be different. Spaces of men considered as publics areas while women's are more private and usually located in or at the back house. Spaces of men generally open without any vertical elements, while spaces of women usually have strong boundaries.

As we indicate in the earlier part of this report, due to limited resource factors, the discussion were started with mixed group between men and women in. Then, in some following question or games, the discussion were splitted between men and women. The process make the opportunity of researcher to observe the difference process of discussion, from the mixed group and the separated group.

Interestingly, we found that from the total of 6 villages, discussion in three villages showing the low participation of women. Our observation depict women rarely speak out, especially when the discussant consist of people from various social strata and combination between men and women. In two discussion that were conducted in one of the house of our discussant, women are prefer to be in the house and answered questions from the house, instead of sitting together in the meeting in the terrace. When the discussion were set to be for women's only, women are more open to speak out. In 
the other three discussion, though some women were dare to speak, but usually only dominated with two or three persons who's indicated as the public figure in the villages. This is confirming the statement of Listiorini (2015) on her paper which illustrate that communication skill of women is usually interpersonal and limited on the homogenous group.

The role of women is actually have recognized by some village leaders. In the comparative visit of nursery group facilitated by ICRAF to Sulawesi, two participants, of the seven participants representing each villages, are women. Actually, ICRAF were not specifically mention that the participants can be either women or men. Based on her performance in the community, these two women's got the opportunity to learn more about nursery practices. However, we understand that this recognition has not been quite uneven across the region. Perhaps this is related to social stratification that still exist in several villages. It's interesting to examine more on this issues.

Looking at the 14 as an aggregrat data from all of the villages, seems that women's and men's perception is almost similar. However, if we go to more detail data per villages, seems that men's and women's have different views on where will be the best place for restoration. Bareland is the place that mostly prefered by the men, while women more prefered to do the restoration or planting in woka. While men focus on how to expand the land, to utilize more land become more productive, and then it could give additional income, women are focus on the efficient thing. Women thought that intensively managed their garden (that near to the residential areas), with adding more high economic value tree commodity, is very low cost and low labour absorption. We might see the difference between men and women, men are usually focus on long term, something related with longterm economic forecast, while women are usually focus on shorter periods and more on economic calculation, reducing the capital through low labour need and low cost on fertilizer etc. Both men's and women's preferences are need to take into account, because both aspect are so important to consider in prior the designing the restoration or rehabilitation program. While looking at the aggregrat data as presented in Figure 14, we commend that the planting for restoration can be done in either bareland or garden, depend on local or village needs.

Weak gender relation is seen while we look at the lowest social status. Maramba is the highest social class, who usually fully control the natural resources in villages. Kabihu, the clan who are free and independent, are able to perform all of their economic activities freely. They have right to choose whatever economic activities they want to take. The lowest group, Ata, have to serve the Maramba. Economic life of Ata were determined by the Maramba (nobleman). Vel and Makabombu (2009, 2010) giving some interesting analysis that women and men from Ata (slave) caste has a very weak position and their decision making power is very limited. From land perspectives, men from slave caste cannot owned the land. Women, both from the lower caste or from the high caste also can only have the land by purchasing or through marriage dowry. Overall, Vel and Makabombu (2009) pointed out that women have limited access and control over land, and even doubled disadvantage if they were in the lower caste. 


\section{Points to note}

Results of this studies shows that womens involvement in restoration are very essential in order to make sure that the restoration process and result that would give more beneficial to the community. Women and men will have different strategies and practices that should be important to take into account in the designing proces, hence, the restoration effort will give benefit to the community and fit with local needs. As we are aware that involving women in the project is a kind of challenge, instead of projects outcome achieved, women even more burdened. Several thing that we should considered in prior:

\section{The practical approach}

Strengthening women's groups. In some villages, since women usually less communicate in the mixed group, would be better if women's groups is separated from the group of men. However, in group activities, with considering the difficulty of the topography and limited water resource, working together between men and women would be the best, as they can help each other. So, the group of women is necessary, but exchange resource between groups of men and women might be a good idea to make sure they will help each other.

\section{The strategic approach}

- Understanding on the importance of giving a chance to women to be actively involved in decision-making for public and social activities, without burdening them, will necessary in household level as well as community level. To accomodate this, more involvement of men in household activities therefore women's burden can be shared.

- Sorting out customary rules which will give possibility to enlarge the gap for women and people on the lower caste to speak out and enforcing their decision making power. 


\section{References}

Forshee J. 2001. Between the Folds: Stories of Cloth, Lives, and Travels from Sumba. University of Hawai'i Press, Honolulu

Fowler C T. 2005. Why is Maize a Sacred Plant? Social History and Agrarian Change on Sumba. Journal of Ethnobiology. 2005 Mar;25(1):39-57.

Fowler C T. 2012. The ecological implications of ancestral religion and reciprocal exchange in a sacred forest in Karendi (Sumba, Indonesia). Worldviews: Global Religions, Culture, and Ecology. 2003 Nov 1;7(3):303-29.

Fox J J. 1980. The flow of life: Essays on eastern Indonesia (No. 2). Harvard University Press.

Janudianto, Dewi S, Martini E, Setiawan A. 2014. Understanding gender perspectives in selecting tree species and farming systems using analytic hierarchy process. In Catacutan D, McGaw E, Llanza M A (Ed). In equal measure: A user guide to gender analysis in agroforestry. ICRAF. Phillipines.

Listiorini D. 2015. Perempuan dalam Komunikasi Pembangunan Pertanian di Sumba Timur. Jurnal Ilmu Komunikasi.11(2).

Melalatoa M J. 1995. Ensiklopedi Suku Bangsa di Indonesia Jilid LZ. Direktorat Jenderal Kebudayaan.

Mulyoutami E, Khususiyah N, Martini E, Suyanto S. 2014. Gender-specific assessment of natural resources using the pebble game. In Catacutan D, McGaw E, Llanza M A (Ed). In equal measure: A user guide to gender analysis in agroforestry. ICRAF. Phillipines. Nurdiah E A, Altrerosje A S, Hariyanto A D. 2016. Gendered Space in West Sumba Traditional Houses. Dimensi (Journal Of Architecture And Built Environment). 42(2):69-76.

Onvlee L. 1980. The significance of livestock on Sumba. In Fox J J (Ed). The Flow of Life: Essays on Eastern Indonesia. Cambridge: Harvard University Press, pp 195-207.

Palekahelu D T. 2010. Marapu: Kekuatan di Balik Kekeringan Potret Masyarakat Wunga Kabupaten Sumba Timur Propinsi NTT (Doctoral dissertation, Doktor Studi Pembangunan Program Pascasarjana UKSW).

Renda T. 2012.. Studi Kasus Tentang Perubahan Sosial di Sumba Timur Terhadap Persyaratan Gelar Kebangsawanan. Thesis for Magister in Sosiology of Religion: Satya Wacana Christian University.

Soelarto, B. 2000. Budaya Sumba. Direktorat Jenderal Kebudayaan.

Vel J A, Makambombu S. 2009. Access in Land Disputes Arising in the Context of the Commercialization of Agriculture in Sumba (Nusa Tenggara Timur). Van Vollenhoven Institute Working Papers. 2009.

Vel J A, Makambombu S. 2010. Access to agrarian justice in Sumba, Eastern Indonesia. Law, Social Justice and Global Development Journal. 1;15.

Wellem F D. 2004. Injil dan Marapu, Suatu studi historis-teologis tentang perjumpaan injil dengan masyarakat Sumba pada periode 1876-1990. Jakarta: BPK Gunung Mulia. 424 p. 



\section{WORKING PAPERS WITH DOIs}

2005

1. Agroforestry in the drylands of eastern Africa: a call to action

2. Biodiversity conservation through agroforestry: managing tree species diversity within a network of community-based, nongovernmental, governmental and research organizations in western Kenya.

3. Invasion of prosopis juliflora and local livelihoods: Case study from the Lake Baringo area of Kenya

4. Leadership for change in farmers organizations: Training report: Ridar Hotel, Kampala, 29th March to 2nd April 2005.

5. Domestication des espèces agroforestières au Sahel : situation actuelle et perspectives

6. Relevé des données de biodiversité ligneuse: Manuel du projet biodiversité des parcs agroforestiers au Sahel

7. Improved land management in the Lake Victoria Basin: TransVic Project's draft report.

8. Livelihood capital, strategies and outcomes in the Taita hills of Kenya

9. Les espèces ligneuses et leurs usages: Les préférences des paysans dans le Cercle de Ségou, au Mali

10. La biodiversité des espèces ligneuses: Diversité arborée et unités de gestion du terroir dans le Cercle de Ségou, au Mali

\section{6}

11. Bird diversity and land use on the slopes of Mt. Kilimanjaro and the adjacent plains, Tanzania

12. Water, women and local social organization in the Western Kenya Highlands

13. Highlights of ongoing research of the World Agroforestry Centre in Indonesia

14. Prospects of adoption of tree-based systems in a rural landscape and its likely impacts on carbon stocks and farmers' welfare: The FALLOW Model Application in Muara Sungkai, Lampung, Sumatra, in a 'Clean Development Mechanism' context

15. Equipping integrated natural resource managers for healthy Agroforestry landscapes.

17. Agro-biodiversity and CGIAR tree and forest science: approaches and examples from Sumatra.

18. Improving land management in eastern and southern Africa: A review of policies.

19. Farm and household economic study of Kecamatan Nanggung, Kabupaten Bogor, Indonesia: A socio-economic base line study of Agroforestry innovations and livelihood enhancement.

20. Lessons from eastern Africa's unsustainable charcoal business.

21. Evolution of RELMA's approaches to land management: Lessons from two decades of research and development in eastern and southern Africa

22. Participatory watershed management: Lessons from RELMA's work with farmers in eastern Africa.

23. Strengthening farmers' organizations: The experience of RELMA and ULAMP.

24. Promoting rainwater harvesting in eastern and southern Africa.

25. The role of livestock in integrated land management.

26. Status of carbon sequestration projects in Africa: Potential benefits and challenges to scaling up. 
27. Social and Environmental Trade-Offs in Tree Species Selection: A Methodology for Identifying Niche Incompatibilities in Agroforestry [Appears as AHI Working Paper no. 9]

28. Managing tradeoffs in agroforestry: From conflict to collaboration in natural resource management. [Appears as AHI Working Paper no. 10]

29. Essai d'analyse de la prise en compte des systemes agroforestiers pa les legislations forestieres au Sahel: Cas du Burkina Faso, du Mali, du Niger et du Senegal.

30. Etat de la recherche agroforestière au Rwanda etude bibliographique, période 1987-2003

2007

31. Science and technological innovations for improving soil fertility and management in Africa: A report for NEPAD's Science and Technology Forum.

32. Compensation and rewards for environmental services.

33. Latin American regional workshop report compensation.

34. Asia regional workshop on compensation ecosystem services.

35. Report of African regional workshop on compensation ecosystem services.

36. Exploring the inter-linkages among and between compensation and rewards for ecosystem services CRES and human well-being

37. Criteria and indicators for environmental service compensation and reward mechanisms: realistic, voluntary, conditional and pro-poor

38. The conditions for effective mechanisms of compensation and rewards for environmental services.

39. Organization and governance for fostering Pro-Poor Compensation for Environmental Services.

40. How important are different types of compensation and reward mechanisms shaping poverty and ecosystem services across Africa, Asia \& Latin America over the Next two decades?

41. Risk mitigation in contract farming: The case of poultry, cotton, woodfuel and cereals in East Africa.

42. The RELMA savings and credit experiences: Sowing the seed of sustainability

43. Yatich J., Policy and institutional context for NRM in Kenya: Challenges and opportunities for Landcare.

44. Nina-Nina Adoung Nasional di So! Field test of rapid land tenure assessment (RATA) in the Batang Toru Watershed, North Sumatera.

45. Is Hutan Tanaman Rakyat a new paradigm in community based tree planting in Indonesia?

46. Socio-Economic aspects of brackish water aquaculture (Tambak) production in Nanggroe Aceh Darrusalam.

47. Farmer livelihoods in the humid forest and moist savannah zones of Cameroon.

48. Domestication, genre et vulnérabilité : Participation des femmes, des Jeunes et des catégories les plus pauvres à la domestication des arbres agroforestiers au Cameroun.

49. Land tenure and management in the districts around Mt Elgon: An assessment presented to the Mt Elgon ecosystem conservation programme.

50. The production and marketing of leaf meal from fodder shrubs in Tanga, Tanzania: A pro-poor enterprise for improving livestock productivity.

51. Buyers Perspective on Environmental Services (ES) and Commoditization as an approach to liberate ES markets in the Philippines. 
52. Towards Towards community-driven conservation in southwest China: Reconciling state and local perceptions.

53. Biofuels in China: An Analysis of the Opportunities and Challenges of Jatropha curcas in Southwest China.

54. Jatropha curcas biodiesel production in Kenya: Economics and potential value chain development for smallholder farmers

55. Livelihoods and Forest Resources in Aceh and Nias for a Sustainable Forest Resource Management and Economic Progress

56. Agroforestry on the interface of Orangutan Conservation and Sustainable Livelihoods in Batang Toru, North Sumatra.

\section{8}

57. Assessing Hydrological Situation of Kapuas Hulu Basin, Kapuas Hulu Regency, West Kalimantan.

58. Assessing the Hydrological Situation of Talau Watershed, Belu Regency, East Nusa Tenggara.

59. Kajian Kondisi Hidrologis DAS Talau, Kabupaten Belu, Nusa Tenggara Timur.

60. Kajian Kondisi Hidrologis DAS Kapuas Hulu, Kabupaten Kapuas Hulu, Kalimantan Barat.

61. Lessons learned from community capacity building activities to support agroforest as sustainable economic alternatives in Batang Toru orang utan habitat conservation program (Martini, Endri et al.)

62. Mainstreaming Climate Change in the Philippines.

63. A Conjoint Analysis of Farmer Preferences for Community Forestry Contracts in the Sumber Jaya Watershed, Indonesia.

64. The highlands: a shared water tower in a changing climate and changing Asia

65. Eco-Certification: Can It Deliver Conservation and Development in the Tropics.

66. Designing ecological and biodiversity sampling strategies. Towards mainstreaming climate change in grassland management.

67. Towards mainstreaming climate change in grassland management policies and practices on the Tibetan Plateau

68. An Assessment of the Potential for Carbon Finance in Rangelands

69 ECA Trade-offs Among Ecosystem Services in the Lake Victoria Basin.

69. The last remnants of mega biodiversity in West Java and Banten: an in-depth exploration of RaTA (Rapid Land Tenure Assessment) in Mount Halimun-Salak National Park Indonesia

70. Le business plan d'une petite entreprise rurale de production et de commercialisation des plants des arbres locaux. Cas de quatre pépinières rurales au Cameroun.

71. Les unités de transformation des produits forestiers non ligneux alimentaires au Cameroun. Diagnostic technique et stratégie de développement Honoré Tabuna et Ingratia Kayitavu.

72. Les exportateurs camerounais de safou (Dacryodes edulis) sur le marché sous régional et international. Profil, fonctionnement et stratégies de développement.

73. Impact of the Southeast Asian Network for Agroforestry Education (SEANAFE) on agroforestry education capacity.

74. Setting landscape conservation targets and promoting them through compatible land use in the Philippines.

75. Review of methods for researching multistrata systems. 
76. Study on economical viability of Jatropha curcas L. plantations in Northern Tanzania assessing farmers' prospects via cost-benefit analysis

77. Cooperation in Agroforestry between Ministry of Forestry of Indonesia and International Center for Research in Agroforestry

78. "China's bioenergy future. an analysis through the Lens if Yunnan Province

79. Land tenure and agricultural productivity in Africa: A comparative analysis of the economics literature and recent policy strategies and reforms

80. Boundary organizations, objects and agents: linking knowledge with action in Agroforestry watersheds

81. Reducing emissions from deforestation and forest degradation (REDD) in Indonesia: options and challenges for fair and efficient payment distribution mechanisms

2009

82. Mainstreaming climate change into agricultural education: challenges and perspectives

83. Challenging conventional mindsets and disconnects in conservation: the emerging role of ecoagriculture in Kenya's landscape mosaics

84. Lesson learned RATA garut dan bengkunat: suatu upaya membedah kebijakan pelepasan kawasan hutan dan redistribusi tanah bekas kawasan hutan

85. The emergence of forest land redistribution in Indonesia

86. Commercial opportunities for fruit in Malawi

87. Status of fruit production processing and marketing in Malawi

88. Fraud in tree science

89. Trees on farm: analysis of global extent and geographical patterns of agroforestry

90. The springs of Nyando: water, social organization and livelihoods in Western Kenya

91. Building capacity toward region-wide curriculum and teaching materials development in agroforestry education in Southeast Asia

92. Overview of biomass energy technology in rural Yunnan (Chinese - English abstract)

93. A pro-growth pathway for reducing net GHG emissions in China

94. Analysis of local livelihoods from past to present in the central Kalimantan Ex-Mega Rice Project area

95. Constraints and options to enhancing production of high quality feeds in dairy production in Kenya, Uganda and Rwanda

2010

96. Agroforestry education in the Philippines: status report from the Southeast Asian Network for Agroforestry Education (SEANAFE)

97. Economic viability of Jatropha curcas L. plantations in Northern Tanzania- assessing farmers' prospects via cost-benefit analysis.

98. Hot spot of emission and confusion: land tenure insecurity, contested policies and competing claims in the central Kalimantan Ex-Mega Rice Project area

99. Agroforestry competences and human resources needs in the Philippines

100. CES/COS/CIS paradigms for compensation and rewards to enhance environmental Services 
101. Case study approach to region-wide curriculum and teaching materials development in agroforestry education in Southeast Asia

102. Stewardship agreement to reduce emissions from deforestation and degradation (REDD): Lubuk Beringin's Hutan Desa as the first village forest in Indonesia

103. Landscape dynamics over time and space from ecological perspective

104. Komoditisasi atau koinvestasi jasa lingkungan: skema imbal jasa lingkungan program peduli sungai di DAS Way Besai, Lampung, Indonesia

105. Improving smallholders' rubber quality in Lubuk Beringin, Bungo district, Jambi province, Indonesia: an initial analysis of the financial and social benefits

106. Rapid Carbon Stock Appraisal (RACSA) in Kalahan, Nueva Vizcaya, Philippines

107. Tree domestication by ICRAF and partners in the Peruvian Amazon: lessons learned and future prospects in the domain of the Amazon Initiative eco-regional program

108. Memorias del Taller Nacional: "Iniciativas para Reducir la Deforestación en la region Andino Amazónica", 09 de Abril del 2010. Proyecto REALU Peru

109. Percepciones sobre la Equidad y Eficiencia en la cadena de valor de REDD en Perú -Reporte de Talleres en Ucayali, San Martín y Loreto, 2009. Proyecto REALU-Perú.

110. Reducción de emisiones de todos los Usos del Suelo. Reporte del Proyecto REALU Perú Fase 1

111. Programa Alternativas a la Tumba-y-Quema (ASB) en el Perú. Informe Resumen y Síntesis de la Fase II. 2da. versión revisada

112. Estudio de las cadenas de abastecimiento de germoplasma forestal en la amazonía Boliviana

113. Biodiesel in the Amazon

114. Estudio de mercado de semillas forestales en la amazonía Colombiana

115. Estudio de las cadenas de abastecimiento de germoplasma forestal en Ecuador http://dx.doi.org10.5716/WP10340.PDF

116. How can systems thinking, social capital and social network analysis help programs achieve impact at scale?

117. Energy policies, forests and local communities in the Ucayali Region, Peruvian Amazon

118. NTFPs as a Source of Livelihood Diversification for Local Communities in the Batang Toru Orangutan Conservation Program

119. Studi Biodiversitas: Apakah agroforestry mampu mengkonservasi keanekaragaman hayati di DAS Konto?

120. Estimasi Karbon Tersimpan di Lahan-lahan Pertanian di DAS Konto, Jawa Timur

121. Implementasi Kaji Cepat Hidrologi (RHA) di Hulu DAS Brantas, Jawa Timur. http://dx.doi.org/10.5716/WP10338.PDF

122. Kaji Cepat Hidrologi di Daerah Aliran Sungai Krueng Peusangan, NAD,Sumatra http://dx.doi.org/10.5716/WP10337.PDF

123. A Study of Rapid Hydrological Appraisal in the Krueng Peusangan Watershed, NAD, Sumatra. http://dx.doi.org/10.5716/WP10339.PDF

2011

124. An Assessment of farm timber value chains in Mt Kenya area, Kenya

125. A Comparative financial analysis of current land use systems and implications for the adoption of improved agroforestry in the East Usambaras, Tanzania

126. Agricultural monitoring and evaluation systems 
127. Challenges and opportunities for collaborative landscape governance in the East Usambara Mountains, Tanzania

128. Transforming Knowledge to Enhance Integrated Natural Resource Management Research, Development and Advocacy in the Highlands of Eastern Africa http://dx.doi.org/10.5716/WP11084.PDF

129. Carbon-forestry projects in the Philippines: potential and challenges The Mt Kitanglad Range forest-carbon development http://dx.doi.org10.5716/WP11054.PDF

130. Carbon forestry projects in the Philippines: potential and challenges. The Arakan Forest Corridor forest-carbon project. http://dx.doi.org10.5716/WP11055.PDF

131. Carbon-forestry projects in the Philippines: potential and challenges. The Laguna Lake Development Authority's forest-carbon development project. http://dx.doi.org/10.5716/WP11056.PDF

132. Carbon-forestry projects in the Philippines: potential and challenges. The Quirino forest-carbon development project in Sierra Madre Biodiversity Corridor http://dx.doi.org10.5716/WP11057.PDF

133. Carbon-forestry projects in the Philippines: potential and challenges. The Ikalahan Ancestral Domain forest-carbon development http://dx.doi.org10.5716/WP11058.PDF

134. The Importance of Local Traditional Institutions in the Management of Natural Resources in the Highlands of Eastern Africa. http://dx.doi.org/10.5716/WP11085.PDF

135. Socio-economic assessment of irrigation pilot projects in Rwanda. http://dx.doi.org/10.5716/WP11086.PDF

136. Performance of three rambutan varieties (Nephelium lappaceum L.) on various nursery media. http://dx.doi.org/10.5716/WP11232.PDF

137. Climate change adaptation and social protection in agroforestry systems: enhancing adaptive capacity and minimizing risk of drought in Zambia and Honduras http://dx.doi.org/10.5716/WP11269.PDF

138. Does value chain development contribute to rural poverty reduction? Evidence of asset building by smallholder coffee producers in Nicaragua http://dx.doi.org/10.5716/WP11271.PDF

139. Potential for biofuel feedstock in Kenya. http://dx.doi.org/10.5716/WP11272.PDF

140. Impact of fertilizer trees on maize production and food security in six districts of Malawi. http://dx.doi.org/10.5716/WP11281.PDF

2012

141. Fortalecimiento de capacidades para la gestión del Santuario Nacional Pampa Hermosa: Construyendo las bases para un manejo adaptativo para el desarrollo local. Memorias del Proyecto. http://dx.doi.org/10.5716/WP12005.PDF

142. Understanding rural institutional strengthening: A cross-level policy and institutional framework for sustainable development in Kenya http://dx.doi.org/10.5716/WP12012.PDF

143. Climate change vulnerability of agroforestry http://dx.doi.org/10.5716/WP16722.PDF

144. Rapid assesment of the inner Niger delta of Mali http://dx.doi.org/10.5716/WP12021.PDF

145. Designing an incentive program to reduce on-farm deforestationin the East Usambara Mountains, Tanzania http://dx.doi.org/10.5716/WP12048.PDF

146. Extent of adoption of conservation agriculture and agroforestry in Africa: the case of Tanzania, Kenya, Ghana, and Zambia http://dx.doi.org/10.5716/WP12049.PDF 
147. Policy incentives for scaling up conservation agriculture with trees in Africa: the case of Tanzania, Kenya, Ghana and Zambia http://dx.doi.org/10.5716/WP12050.PDF

148. Commoditized or co-invested environmental services? Rewards for environmental services scheme: River Care program Way Besai watershed, Lampung, Indonesia.

http://dx.doi.org/10.5716/WP12051.PDF

149. Assessment of the headwaters of the Blue Nile in Ethiopia. http://dx.doi.org/10.5716/WP12160.PDF

150. Assessment of the uThukela Watershed, Kwazaulu. http://dx.doi.org/10.5716/WP12161.PDF

151. Assessment of the Oum Zessar Watershed of Tunisia. http://dx.doi.org/10.5716/WP12162.PDF

152. Assessment of the Ruwenzori Mountains in Uganda. http://dx.doi.org/10.5716/WP12163.PDF

153. History of agroforestry research and development in Viet Nam. Analysis of research opportunities and gaps. http://dx.doi.org/10.5716/WP12052.PDF

154. REDD+ in Indonesia: a Historical Perspective. http://dx.doi.org/10.5716/WP12053.PDF

155. Agroforestry and Forestry in Sulawesi series: Livelihood strategies and land use system dynamics in South Sulawesi http://dx.doi.org/10.5716/WP12054.PDF

156. Agroforestry and Forestry in Sulawesi series: Livelihood strategies and land use system dynamics in Southeast Sulawesi. http://dx.doi.org/10.5716/WP12055.PDF

157. Agroforestry and Forestry in Sulawesi series: Profitability and land-use systems in South and Southeast Sulawesi. http://dx.doi.org/10.5716/WP12056.PDF

158. Agroforestry and Forestry in Sulawesi series: Gender, livelihoods and land in South and Southeast Sulawesi http://dx.doi.org/10.5716/WP12057.PDF

159. Agroforestry and Forestry in Sulawesi series: Agroforestry extension needs at the community level in AgFor project sites in South and Southeast Sulawesi, Indonesia. http://dx.doi.org/10.5716/WP12058.PDF

160. Agroforestry and Forestry in Sulawesi series: Rapid market appraisal of agricultural, plantation and forestry commodities in South and Southeast Sulawesi.

http://dx.doi.org/10.5716/WP12059.PDF

2013

161. Diagnosis of farming systems in the Agroforestry for Livelihoods of Smallholder farmers in Northwestern Viet Nam project http://dx.doi.org/10.5716/WP13033.PDF

162. Ecosystem vulnerability to climate change: a literature review. http://dx.doi.org/10.5716/WP13034.PDF

163. Local capacity for implementing payments for environmental services schemes: lessons from the RUPES project in northeastern Viet Nam http://dx.doi.org/10.5716/WP13046.PDF

164. Seri Agroforestri dan Kehutanan di Sulawesi: Agroforestry dan Kehutanan di Sulawesi: Strategi mata pencaharian dan dinamika sistem penggunaan lahan di Sulawesi Selatan http://dx.doi.org/10.5716/WP13040.PDF

165. Seri Agroforestri dan Kehutanan di Sulawesi: Mata pencaharian dan dinamika sistem penggunaan lahan di Sulawesi Tenggara http://dx.doi.org/10.5716/WP13041.PDF

166. Seri Agroforestri dan Kehutanan di Sulawesi: Profitabilitas sistem penggunaan lahan di Sulawesi Selatan dan Sulawesi Tenggara http://dx.doi.org/10.5716/WP13042.PDF

167. Seri Agroforestri dan Kehutanan di Sulawesi: Gender, mata pencarian dan lahan di Sulawesi Selatan dan Sulawesi Tenggara http://dx.doi.org/10.5716/WP13043.PDF 
168. Seri Agroforestri dan Kehutanan di Sulawesi: Kebutuhan penyuluhan agroforestri pada tingkat masyarakat di lokasi proyek AgFor di Sulawesi Selatan dan Tenggara, Indonesia. http://dx.doi.org/10.5716/WP13044.PDF

169. Seri Agroforestri dan Kehutanan di Sulawesi: Laporan hasil penilaian cepat untuk komoditas pertanian, perkebunan dan kehutanan di Sulawesi Selatan dan Tenggara http://dx.doi.org/10.5716/WP13045.PDF

170. Agroforestry, food and nutritional security http://dx.doi.org/10.5716/WP13054.PDF

171. Stakeholder Preferences over Rewards for Ecosystem Services: Implications for a REDD+ Benefit Distribution System in Viet Nam http://dx.doi.org/10.5716/WP13057.PDF

172. Payments for ecosystem services schemes: project-level insights on benefits for ecosystems and the rural poor http://dx.doi.org/10.5716/WP13001.PDF

173. Good practices for smallholder teak plantations: keys to success http://dx.doi.org/10.5716/WP13246.PDF

174. Market analysis of selected agroforestry products in the Vision for Change Project intervention Zone, Côte d'Ivoire http://dx.doi.org/10.5716/WP13249.PDF

175. Rattan futures in Katingan: why do smallholders abandon or keep their gardens in Indonesia's 'rattan district'? http://dx.doi.org/10.5716/WP13251.PDF

176. Management along a gradient: the case of Southeast Sulawesi's cacao production landscapes http://dx.doi.org/10.5716/WP13265.PDF

2014

177. Are trees buffering ecosystems and livelihoods in agricultural landscapes of the Lower Mekong Basin? Consequences for climate-change adaptation. http://dx.doi.org/10.5716/WP14047.PDF

178. Agroforestry, livestock, fodder production and climate change adaptation and mitigation in East Africa: issues and options. http://dx.doi.org/10.5716/WP14050.PDF

179. Trees on farms: an update and reanalysis of agroforestry's global extent and socio-ecological characteristics. http://dx.doi.org/10.5716/WP14064.PDF

180. Beyond reforestation: an assessment of Vietnam's REDD+ readiness. http://dx.doi.org/10.5716/WP14097.PDF

181. Farmer-to-farmer extension in Kenya: the perspectives of organizations using the approach. http://dx.doi.org/10.5716/WP14380.PDF

182. Farmer-to-farmer extension in Cameroon: a survey of extension organizations. http://dx.doi.org/10.5716/WP14383.PDF

183. Farmer-to-farmer extension approach in Malawi: a survey of organizations: a survey of organizations http://dx.doi.org/10.5716/WP14391.PDF

184. Seri Agroforestri dan Kehutanan di Sulawesi: Kuantifikasi jasa lingkungan air dan karbon pola agroforestri pada hutan rakyat di wilayah sungai Jeneberang

185. Options for Climate-Smart Agriculture at Kaptumo Site in Kenyahttp://dx.doi.org/10.5716/WP14394.PDF

2015

186. Agroforestry for Landscape Restoration and Livelihood Development in Central Asia http://dx.doi.org/10.5716/WP14143.PDF 
187. "Projected Climate Change and Impact on Bioclimatic Conditions in the Central and SouthCentral Asia Region" http://dx.doi.org/10.5716/WP14144.PDF

188. Land Cover Changes, Forest Loss and Degradation in Kutai Barat, Indonesia. http://dx.doi.org/10.5716/WP14145.PDF

189. The Farmer-to-Farmer Extension Approach in Malawi: A Survey of Lead Farmers. http://dx.doi.org/10.5716/WP14152.PDF

190. Evaluating indicators of land degradation and targeting agroforestry interventions in smallholder farming systems in Ethiopia. http://dx.doi.org/10.5716/WP14252.PDF

191. Land health surveillance for identifying land constraints and targeting land management options in smallholder farming systems in Western Cameroon

192. Land health surveillance in four agroecologies in Malawi

193. Cocoa Land Health Surveillance: an evidence-based approach to sustainable management of cocoa landscapes in the Nawa region, South-West Côte d'Ivoire http://dx.doi.org/10.5716/WP14255.PDF

194. Situational analysis report: Xishuangbanna autonomous Dai Prefecture, Yunnan Province, China. http://dx.doi.org/10.5716/WP14255.PDF

195. Farmer-to-farmer extension: a survey of lead farmers in Cameroon. http://dx.doi.org/10.5716/WP15009.PDF

196. From transition fuel to viable energy source Improving sustainability in the sub-Saharan charcoal sector http://dx.doi.org/10.5716/WP15011.PDF

197. Mobilizing Hybrid Knowledge for More Effective Water Governance in the Asian Highlands http://dx.doi.org/10.5716/WP15012.PDF

198. Water Governance in the Asian Highlands http://dx.doi.org/10.5716/WP15013.PDF

199. Assessing the Effectiveness of the Volunteer Farmer Trainer Approach in Dissemination of Livestock Feed Technologies in Kenya vis-à-vis other Information Sources http://dx.doi.org/10.5716/WP15022.PDF

200. The rooted pedon in a dynamic multifunctional landscape: Soil science at the World Agroforestry Centre http://dx.doi.org/10.5716/WP15023.PDF

201. Characterising agro-ecological zones with local knowledge. Case study: Huong Khe district, $\mathrm{Ha}$ Tinh, Viet Nam http://dx.doi.org/10.5716/WP15050.PDF

202. Looking back to look ahead: Insight into the effectiveness and efficiency of selected advisory approaches in the dissemination of agricultural technologies indicative of Conservation Agriculture with Trees in Machakos County, Kenya. http://dx.doi.org/10.5716/WP15065.PDF

203. Pro-poor Biocarbon Projects in Eastern Africa Economic and Institutional Lessons. http://dx.doi.org/10.5716/WP15022.PDF

204. Projected climate change impacts on climatic suitability and geographical distribution of banana and coffee plantations in Nepal. http://dx.doi.org/10.5716/WP15294.PDF

205. Agroforestry and Forestry in Sulawesi series: Smallholders' coffee production and marketing in Indonesia. A case study of two villages in South Sulawesi Province. http://dx.doi.org/10.5716/WP15690.PDF

206. Mobile phone ownership and use of short message service by farmer trainers: a case study of Olkalou and Kaptumo in Kenya http://dx.doi.org/10.5716/WP15691.PDF

207. Associating multivariate climatic descriptors with cereal yields: a case study of Southern Burkina Faso http://dx.doi.org/10.5716/WP15273.PDF

208. Preferences and adoption of livestock feed practices among farmers in dairy management groups in Kenya http://dx.doi.org/10.5716/WP15675.PDF 
209. Scaling up climate-smart agriculture: lessons learned from South Asia and pathways for success http://dx.doi.org/10.5716/WP15720.PDF

210. Agroforestry and Forestry in Sulawesi series: Local perceptions of forest ecosystem services and collaborative formulation of reward mechanisms in South and Southeast Sulawesi http://dx.doi.org/10.5716/WP15721.PDF

211. Potential and challenges in implementing the co-investment of ecosystem services scheme in Buol District, Indonesia. http://dx.doi.org/10.5716/WP15722.PDF

212. Tree diversity and its utilization by the local community in Buol District, Indonesia http://dx.doi.org/10.5716/WP15723.PDF

213 Vulnerability of smallholder farmers and their preferences on farming practices in Buol District, Indonesia http://dx.doi.org/10.5716/WP15724.PDF

214. Dynamics of Land Use/Cover Change and Carbon Emission in Buol District, Indonesia http://dx.doi.org/10.5716/WP15725.PDF

215. Gender perspective in smallholder farming practices in Lantapan, Phillippines. http://dx.doi.org/10.5716/WP15726.PDF

216. Vulnerability of smallholder farmers in Lantapan, Bukidnon. http://dx.doi.org/10.5716/WP15727.PDF

217. Vulnerability and adaptive capacity of smallholder farmers in Ho Ho Sub-watershed, Ha Tinh Province, Vietnam http://dx.doi.org/10.5716/WP15728.PDF

218. Local Knowledge on the role of trees to enhance livelihoods and ecosystem services in northern central Vietnam http://dx.doi.org/10.5716/WP15729.PDF

219. Land-use/cover change in Ho Ho Sub-watershed, Ha Tinh Province, Vietnam. http://dx.doi.org/10.5716/WP15730.PDF

2016

220. Agroforestry and Forestry in Sulawesi series: Evaluation of the Agroforestry Farmer Field Schools on agroforestry management in South and Southeast Sulawesi, Indonesia. http://dx.doi.org/10.5716/WP16002.PDF

221. Farmer-to-farmer extension of livestock feed technologies in Rwanda: A survey of volunteer farmer trainers and organizations. http://dx.doi.org/10.5716/WP16005.PDF

222. Projected Climate Change Impact on Hydrology, Bioclimatic Conditions, and Terrestrial Ecosystems in the Asian Highlands http://dx.doi.org/10.5716/WP16006.PDF

223. Adoption of Agroforestry and its impact on household food security among farmers in Malawi http://dx.doi.org/10.5716/WP16013.PDF

224. Agroforestry and Forestry in Sulawesi series: Information channels for disseminating innovative agroforestry practices to villages in Southern Sulawesi, Indonesia http://dx.doi.org/10.5716/WP16034.PDF

225. Agroforestry and Forestry in Sulawesi series: Unravelling rural migration networks.Landtenure arrangements among Bugis migrant communities in Southeast Sulawesi. http://dx.doi.org/10.5716/WP16035.PDF

226. Agroforestry and Forestry in Sulawesi series: Women's participation in agroforestry: more benefit or burden? A gendered analysis of Gorontalo Province. http://dx.doi.org/10.5716/WP16036.PDF

227. Kajian Kelayakan dan Pengembangan Desain Teknis Rehabilitasi Pesisir di Sulawesi Tengah. http://dx.doi.org/10.5716/WP16037.PDF

228. Selection of son tra clones in North West Vietnam. http://dx.doi.org/10.5716/WP16038.PDF 
229. Growth and fruit yield of seedlings, cuttings and grafts from selected son tra trees in Northwest Vietnam http://dx.doi.org/10.5716/WP16046.PDF

230. Gender-Focused Analysis of Poverty and Vulnerability in Yunnan, China http://dx.doi.org/10.5716/WP16071.PDF

231. Seri Agroforestri dan Kehutanan di Sulawesi: Kebutuhan Penyuluhan Agroforestri untuk Rehabilitasi Lahan di Sumba Timur, Nusa Tenggara Timur, Indonesia. http://dx.doi.org/10.5716/WP16077.PDF

232. Agroforestry and Forestry in Sulawesi series: Agroforestry extension needs for land rehabilitation in East Sumba, East Nusa Tenggara, Indonesia. http://dx.doi.org/10.5716/WP16078.PDF

233. Central hypotheses for the third agroforestry paradigm within a common definition. http://dx.doi.org/10.5716/WP16079.PDF

234. Assessing smallholder farmers' interest in shade coffee trees: The Farming Systems of Smallholder Coffee Producers in the Gisenyi Area, Rwanda: a participatory diagnostic study. http://dx.doi.org/10.5716/WP16104.PDF

235. Review of agricultural market information systems in |sub-Saharan Africa. http://dx.doi.org/10.5716/WP16110.PDF

236. Vision and road map for establishment of a protected area in Lag Badana, Lower Jubba, Somalia. http://dx.doi.org/10.5716/WP16127.PDF

237. Replicable tools and frameworks for Bio-Carbon Development in West Africa. http://dx.doi.org/10.5716/WP16138.PDF

238. Existing Conditions, Challenges and Needs in the Implementation of Forestry and Agroforestry Extension in Indonesia. http://dx.doi.org/10.5716/WP16141.PDF

239. Situasi Terkini, Tantangan dan Kebutuhan Pelaksanaan Penyuluhan Kehutanan dan Agroforestri di Indonesia. http://dx.doi.org/10.5716/WP16142.PDF

240. The national agroforestry policy of India: experiential learning in development and delivery phases. http://dx.doi.org/10.5716/WP16143.PDF

241. Agroforestry and Forestry in Sulawesi series: Livelihood strategies and land-use system dynamics in Gorontalo. http://dx.doi.org/10.5716/WP16157.PDF

242. Seri Agroforestri dan Kehutanan di Sulawesi: Strategi mata pencaharian dan dinamika sistem penggunaan lahan di Gorontalo. http://dx.doi.org/10.5716/WP16158.PDF

243. Ruang, Gender dan Kualitas Hidup Manusia: Sebuah studi Gender pada komunitas perantau dan pengelola kebun di Jawa Barat. http://dx.doi.org/10.5716/WP16159.PDF

244. Gendered Knowledge and perception in managing grassland areas in East Sumba, Indonesia. http://dx.doi.org/10.5716/WP16160.PDF 


The World Agroforestry Centre is an autonomous, non-profit research organization whose vision is a rural transformation in the developing world as smallholder households increase their use of trees in agricultural landscapes to improve food security, nutrition, income, health, shelter, social cohesion, energy resources and environmental sustainability. The Centre generates science-based knowledge about the diverse roles that trees play in agricultural landscapes, and uses its research to advance policies and practices, and their implementation that benefit the poor and the environment. It aims to ensure that all this is achieved by enhancing the quality of its science work, increasing operational efficiency, building and maintaining strong partnerships, accelerating the use and impact of its research, and promoting greater cohesion, interdependence and alignment within the organization.

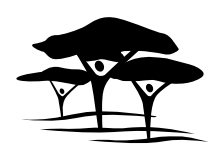

United Nations Avenue, Gigiri • PO Box 30677 • Nairobi, $00100 \cdot$ Kenya Telephone: +254207224000 or via USA +16508336645 Fax: +254207224001 or via USA +16508336646 Email: worldagroforestry@cgiar.org•www.worldagroforestry.org

Southeast Asia Regional Program • Sindang Barang • Bogor 16680 PO Box $161 \cdot$ Bogor $16001 \cdot$ Indonesia

Telephone: +62 $2518625415 \cdot$ Fax: +62 2518625416 